\title{
27. PALEOMAGNETISM OF CRETACEOUS SEDIMENTS, HOLE 869B, MARSHALL ISLANDS: MAGNETIC POLARITY, PALEOLATITUDE, AND A PALEOMAGNETIC POLE ${ }^{1}$
}

\author{
William W. Sager, ${ }^{2}$ John A. Tarduno, ${ }^{3}$ and Christopher J. MacLeod ${ }^{4,5}$
}

\begin{abstract}
Paleolatitudes of sites on the Pacific Plate are poorly constrained for times before the Late Cretaceous, so Cenomanian to early Campanian-early Maastrichtian pelagic and volcaniclastic sediments from Hole 869B gave us the opportunity to obtain Pacific paleomagnetic data for this period. We analyzed azimuthally unoriented samples and calculated a mean inclination and paleolatitude. In addition, we attempted to reorient samples using magnetically oriented formation microscanner (FMS) wireline logs. Inclination values displayed a distinct dichotomy, with means of $-23.2\left(95 \%\right.$ confidence limits: $\left.19.9^{\circ}, 25.7^{\circ} ; N=69\right)$ and $-33.3^{\circ}(95 \%$ confidence limits: $31.1^{\circ}, 35.0^{\circ} ; N=60$ ), implying paleolatitudes of $12.1^{\circ} \mathrm{S}$ and $18.2^{\circ} \mathrm{S}$, respectively. The steeper inclination agrees with other Pacific paleomagnetic data and implies that Site 869 was near the southern limits of the tropics during Cenomanian time. The smaller value seems to result from an inclination-shallowing bias common to many consolidated sediments drilled from the Pacific. Although this bias may be related to sediment texture, the clearest division of inclination groups was made along lithologic unit boundaries. Units that gave seemingly reliable inclinations consist of thicker volcaniclastic turbidites apparently laid down more rapidly than those that gave shallow inclinations. Owing to various difficulties, we were able to reliably orient only eight segments of core by comparison with the FMS log. These gave paleodeclinations that ranged from $-38.1^{\circ}$ to $30.8^{\circ}$, with a standard deviation of $22.8^{\circ}$. We used a maximum-likelihood technique to estimate a paleomagnetic pole using these declinations and the steeper mean inclination. The pole is located at $60.8^{\circ} \mathrm{N}, 347.3^{\circ} \mathrm{E}$ and has a $95 \%$ confidence ellipse with major and minor semiaxes of $21.2^{\circ}$ and $4.9^{\circ}$, the former trending $93^{\circ}$. Biostratigraphy indicates a Cenomanian age for sediments used to determine the pole and a basalt clast from the section gave an ${ }^{40} \mathrm{Ar}-{ }^{39} \mathrm{Ar}$ radiometric age of $96.6 \pm 0.8 \mathrm{Ma}$. This pole is located along the Late Cretaceous Pacific apparent polar wander path, consistent with other paleomagnetic data of similar age. Hole 869B samples had mostly normal-polarity magnetizations, but most in Cores $143-869 \mathrm{~B}-22 \mathrm{R}$ to $-26 \mathrm{R}$ showed reversed polarities. Although the inclination data suggest two reversed polarity zones, we argue that these represent only one, specifically Chron $33 R$, and that the apparent division is a result of a magnetic field excursion, previously recognized at nearby Site 462
\end{abstract}

\section{INTRODUCTION}

Paleomagnetic data from Cretaceous samples, drilled from the seafloor, are important for understanding the tectonics of the Pacific Plate. Paleomagnetic data of Jurassic and Early Cretaceous age suggest that the plate drifted southward (Larson and Lowrie, 1975; Cox and Gordon, 1984; Sager, 1992; Steiner and Wallick, 1992; Larson et al., 1992), whereas Late Cretaceous and Tertiary data show that it subsequently drifted northward (Francheteau et al., 1970; Gordon, 1983; Sager and Pringle, 1988). In between, the plate turned around at equatorial latitudes (Lancelot and Larson, 1975; Steiner and Wallick, 1992; Larson et al., 1992); however, details of the turnabout are unclear owing to the scarcity of paleomagnetic and tectonic data for this period.

Hole 869B penetrated a thick section of Cretaceous clays and volcaniclastic sediments on the distal archipelagic apron of a Marshall Islands island/guyot pair. Most of the section is either Cenomanian or Campanian in age (Fig. 1; Sager, Winterer, Firth, et al., 1993), periods having few drill core paleomagnetic data (Sager and Pringle, 1988), so we seized the opportunity to augment this data set. Furthermore, the acquisition of formation microscanner (FMS) logs from this hole allowed us to attempt the orientation of features in the cores, so that paleomagnetic declination could be calculated, a rarity for samples obtained by rotary drilling. The results from Hole $869 \mathrm{~B}$ provided both promise and problems. The problems arose from apparent shallowing

'Winterer, E.L., Sager, W.W., Firth, J.V., and Sinton, J.M. (Eds.), 1995. Proc, ODP, Sci. Results, 143: College Station, TX (Ocean Drilling Program).

${ }^{2}$ Departments of Oceanography and Geophysics, Texas A\&M University, College Station, TX 77843, U.S.A.

${ }^{3}$ Department of Earth and Environmental Sciences, University of Rochester, Rochester, NY 14627, U.S.A.

${ }^{4}$ Institute of Oceanographic Sciences, Deacon Laboratory, Wormley, Surrey, GU8 $5 \mathrm{UB}$, United Kingdom.

${ }^{5}$ Borehole Research, Department of Geology, University of Leicester, Leicester LE1 7RH, United Kingdom. of inclinations from some units, a bias common with sediments drilled from the deep sea (Gordon, 1990; Tarduno, 1990), and conditions that made it difficult to obtain a large number of reliable, azimuthally oriented samples. Nevertheless, it was possible to determine apparently reliable paleolatitude and paleodeclination, albeit with large uncertainty for the latter. In addition, it was also possible to compare paleoinclination data from different sedimentary units and sediment types to gain insights about the problem of inclination-shallowing.

\section{Geologic Setting}

Hole 869B was drilled at a depth of $4827 \mathrm{~m}$ in the basin near the atoll/guyot pair, Pikinni Atoll and Wodejebato Guyot, in the central Marshall Islands. The site is located approximately $75 \mathrm{~km}$ southwest of the Pikinni-Wodejebato pair, at a location approximately equidistant from each and supposedly on the edifice's distal archipelagic apron, where sediments shed by both might have been deposited.

Pikinni-Wodejebato is one of many volcanic edifices in the Marshall Islands Province. These seamounts sit on seafloor of Jurassic age (Nakanishi et al., 1992), but were probably formed during the mid-Cretaceous by widespread volcanism (Schlanger et al., 1981; Tarduno et al., 1991; Larson, 1991). Before Ocean Drilling Program (ODP) Legs 143 and 144, it was thought that most of the volcanism on Pikinni-Wodejebato occurred before or during Albian time, but drilling showed evidence of significant Cenomanian and Campanian activity (Sager, Winterer, Firth, et al., 1993; Premoli Silva, Haggerty, Rack, et al., 1993).

A thick succession of volcaniclastic sediments was drilled at Site 869 , and the supposition is that these came from the atoll/guyot pair because in seismic reflection profiles the sedimentary layers show a shallow slope $\left(<1^{\circ}\right)$ upward toward the edifice (Sager, Winterer, Firth, et al., 1993). Because some of the volcaniclastics are coarse-grained breccias, grain flows, and mass slides, uncertainty exists about whether all of the volcanics came from as far away as the atoll/guyot 


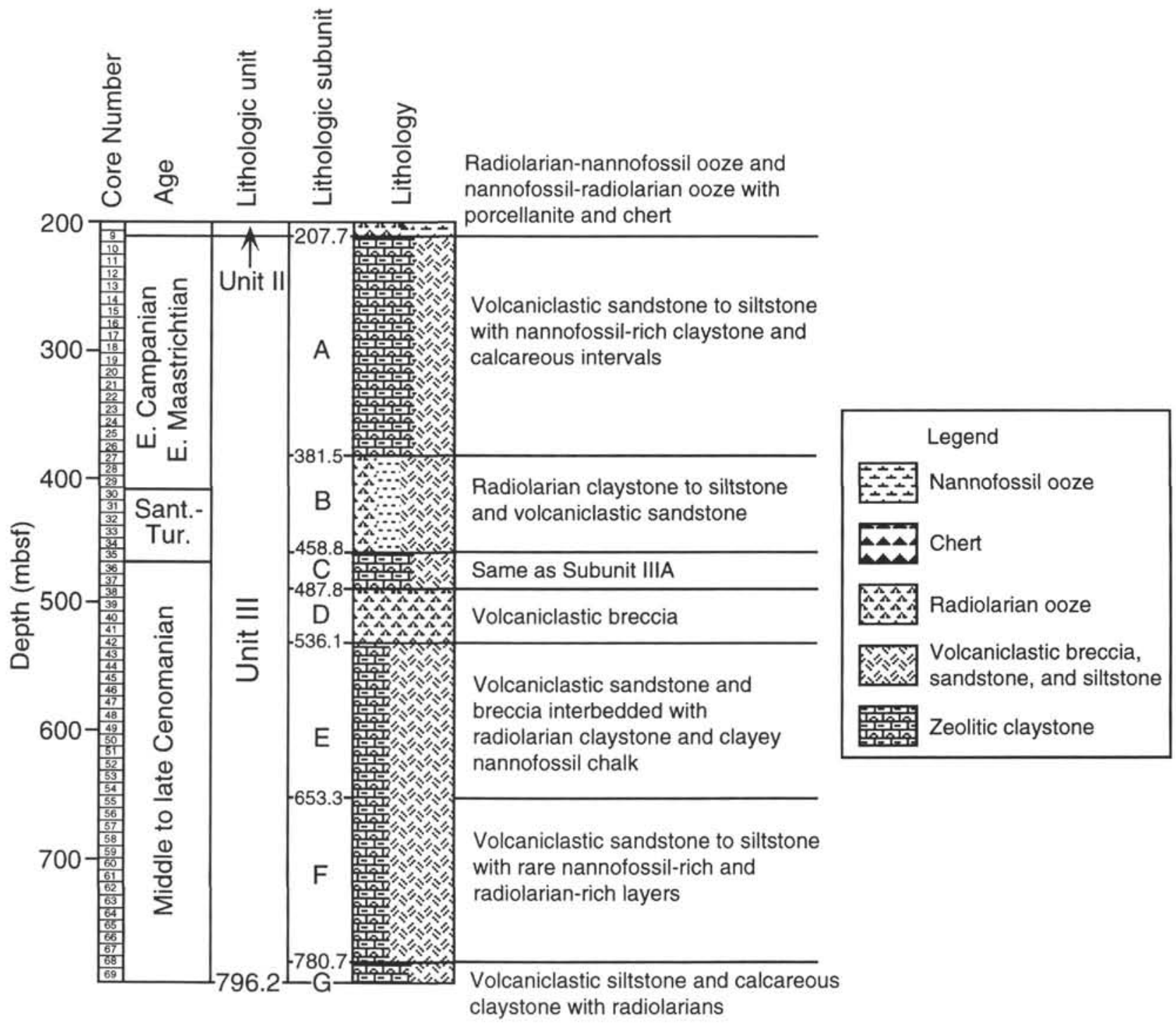

Figure 1. Lithologic column for Hole 869B, which cored the Cretaceous section at Site 869. Core numbers, biostratigraphic ages, and lithologic units and subunits are shown at left. Lithology is shown at right (modified from Sager, Winterer, Firth, et al., 1993).

edifice. It is possible that some of the coarser clastics might have originated from smaller, nearby seamounts, but for the purposes of our study, the distinction is not important.

\section{Hole 869B}

Hole $869 \mathrm{~B}$ was drilled with a rotary core barrel $(\mathrm{RCB})$ and penetrated to a depth of 796.2 mbsf (Fig. 1). After passing through 207.7 $\mathrm{m}$ of Tertiary variably clayey nannofossil ooze, with porcellanite and chert layers in the early Tertiary section, the drill cored volcaniclastic sedimentary rocks interbedded with claystones in the $588.5 \mathrm{~m}$ below (Fig. 1). The volcanic-rich sections range in age from early Maastrichtian to Cenomanian, ages based primarily on calcareous nannofossils, with some constraints from pelagic foraminifers (Sager, Winterer, Firth, et al., 1993). An additional age datum is an ${ }^{40} \mathrm{Ar}-{ }^{39} \mathrm{Ar}$ radiometric date of $96.6 \pm 0.8 \mathrm{Ma}$ from a basalt clast recovered from the Cenomanian section, Core 143-869B-41R, at a depth of $523.6 \mathrm{~m}$ (Pringle and Duncan, this volume).

The Cretaceous sedimentary section was classified by shipboard stratigraphers as a single sedimentary unit containing seven subunits, based on changes in the style of deposition and mix of sedimentary components (Sager, Winterer, Firth, et al., 1993, p. 313). The back- ground sediments appear to have been deep-sea clays of mostly pelagic origin, whose deposition was interrupted by the introduction of varying amounts of volcaniclastic material that ranged in size from silt to basalt blocks $80 \mathrm{~cm}$ in diameter.

In the uppermost approximately $250 \mathrm{~m}$ of the Cretaceous section, the sedimentary beds have small thicknesses, typically millimeters to centimeters, and shallow dips of a few degrees or less (see figs. $16-17$, p. 314 , and fig. 22 , p. 317 in Sager, Winterer, Firth, et al., 1993). These sediments range in age from Santonian-Turonian to early Maastrichtian, but most are early Campanian age, owing to an abundance of volcanism during that stage (Sager, Winterer, Firth, et al., 1993). They comprise sedimentary Subunits IIIA, IIIB, and part of IIIC, which consist of volcaniclastic siltstone to sandstone with radiolarian claystone and calcareous nannofossil-rich interbeds.

Subunits IIID, IIIE, and IIIF were deposited rapidly during the middle to late Cenomanian owing to a massive influx of volcanic detritus. In contrast to the post-Cenomanian sediments, these are characterized by thick volcaniclastic turbidites, grain flows, and mass-flow deposits. Meter-scale layers are typical, but Subunit IIID contains breccia layers tens of meters thick. An outstanding feature of these units is the occurrence of occasional contacts where coarse volcaniclastics, typically a breccia at the base of a turbidite, overlie 
fine-grained volcaniclastic sediments or claystone (see fig. 25 , p. 323 in Sager, Winterer, Firth, et al., 1993). These contacts are clearly erosive, and many display significant slopes $\left(>5^{\circ}\right)$.

Subunit IIIG occurs in the bottom $15 \mathrm{~m}$ of the hole. Although also of Cenomanian age, it shows a style of deposition similar to Subunits IIIA and IIIB and consists mainly of siltstone, claystone, and calcareous claystone. This unit probably indicates a period of slower sedimentation before the rapid influx of volcanic products located immediately above.

Rates of deposition for the Cretaceous sediments are difficult to determine because diagnostic microfossils were scarce and because the sedimentation was obviously episodic owing to turbidity currents and mass flows. Conservative estimates for the Campanian and Cenomanian sections are 15 to 30 and $60 \mathrm{~m} / \mathrm{m}$.y., respectively. The latter value is particularly suspect, owing to the resolution limits of Cretaceous biostratigraphy and uncertainties in Cenomanian biostratigraphic boundaries; the mean sedimentation rate may have been $300 \mathrm{~m} / \mathrm{m} . \mathrm{y}$, or greater (Sager, Winterer, Firth, et al., 1993).

\section{METHODS}

\section{Magnetic Measurements}

Virtually all sediments from Hole 869B were lithified, so sampling was done either by drilling a $2.5-\mathrm{cm}$-diameter minicore, 2.0 to $2.5 \mathrm{~cm}$ in length, perpendicular to the split face of the core, or by sawing a $2.5-\mathrm{cm}$ cube. Both types of samples were oriented with a mark to indicate the upward direction and have volumes of 10 to $12 \mathrm{~cm}^{3}$. About $10 \%$ were measured aboard the ship with the $2 \mathrm{G}$ pass-through cryogenic magnetometer, but the rest were measured with a CTF discretesample magnetometer within a shielded room. In all, 165 samples were analyzed for this study. Because the cores were obtained by rotary drilling, the samples have no consistent azimuthal orientation. However, in many cores, long pieces of continuous core were recovered, and these should give internally consistent magnetic declinations.

About a dozen samples were examined by measuring their acquisition of an isothermal remanent magnetization (IRM) in high magnetic fields. The IRMs were imparted using a pulse-magnetizer, which creates a high field for a short period (about $2 \mathrm{~ms}$ ) by passing a surge of current through a coil. The IRM acquisition behavior is one way of determining whether a sample contains low or high coercivity magnetic grains (e.g., McElhinny, 1973), a factor to be considered when choosing a method to extract the geologically significant magnetization direction.

To isolate the characteristic remanent magnetization (ChRM), that is, the paleomagnetic field direction acquired at the time the sediments were laid down, the samples were treated to stepwise demagnetization procedures. At first, both alternating field $(\mathrm{AF})$ and thermal demagnetization methods were tried, but the latter seemed to give better results, thus it was used on most samples (76\%). All samples were treated to detailed stepwise demagnetization experiments, with most being demagnetized in 10 to 15 steps up to 60 to $80 \mathrm{mT}$ or $500^{\circ}$ to $600^{\circ} \mathrm{C}$. A small percentage were treated to shorter demagnetization sequences, of approximately six steps, when sufficient numbers of adjacent samples had been analyzed to determine optimal demagnetization steps.

Paleomagnetic inclination and declination values were determined by principal component analysis, fitting a line anchored to the origin through the demagnetization steps thought to represent the ChRM (Kirschvink, 1980). The average number of measurements used to determine the ChRM direction was six (Appendix). A maximum angular deviation (MAD) value was determined for each line fit; this angle is akin to angular standard deviation (Kirschvink, 1980) and can be used to judge the reliability of the ChRM direction. In this study, we observed that samples having MAD angles of less than about $2^{\circ}$ to $3^{\circ}$ are typically well-determined, whereas those having angles in excess of about $6^{\circ}$ to $8^{\circ}$ are of least reliability.

\section{Orientation}

Because no working tool exists for orienting rotary-core samples during drilling, we tried two post-drilling methods of reorienting samples to geographic coordinates. First, we performed detailed demagnetization sequences on many of the samples, measuring many steps at low AF fields or temperatures, in an effort to define the directions of magnetic overprints. Although it has been possible to reorient sample ChRM declinations using the overprint direction, assuming the overprint to be a recent, Brunhes Chron, normal polarity overprint that points to north (Shibuya et al., 1991), we found this method to be ineffectual because for the samples in this study, the overprint directions did not appear consistent.

Our second method was to attempt the reorientation of inclined features recognized in both the FMS logs and in the cores. These methods have been described elsewhere (MacLeod et al., 1992; MacLeod et al., 1994; Sager et al., 1994), so we do not discuss them in detail here. The idea is that the dip and dip directions of inclined features cut by the borehole can be imaged by the FMS, a resistivitymeasuring tool having centimeter-scale resolution. The FMS uses a three-component magnetometer for orientation purposes, so the logs can be oriented relative to geographic coordinates. We looked for distinctive features that appeared in the FMS log that could be reasonably identified in the cores. These were typically breccia-base contacts, coarse layers, or steeply dipping beds. Using proprietary Schlumberger software that fits a sinusoid to planar features cut by the borehole, the dips and dip directions of these features were calculated (e.g., MacLeod et al., 1994). In the cores, dips and dip directions (in core coordinates) were determined from direct measurement (Sager et al., 1994), and a correction was applied to the paleomagnetic declinations of samples from contiguous parts of the core. This amounts to a rotation of the sample direction around a vertical axis. Because sedimentary features in Hole 869B were thought not to have been tilted, we made no structural corrections for the dips of the features. Typically, we analyzed two to four samples per feature, depending on the size of the contiguous core pieces.

\section{Paleomagnetic Directions}

From ChRM directions, we determined two types of means: mean inclination (and paleolatitude) using no declination data, and paleomagnetic poles, using FMS-oriented paleodeclinations. Inclinationonly data have an inherent bias that shallows the mean because a twodimensional distribution of poles, having circular symmetry, maps asymmetrically into a one-dimensional distribution (Briden and Ward, 1966; McFadden and Reid, 1982; Cox and Gordon, 1984). We used the biascorrection method of McFadden and Reid (1982) to calculate mean inclinations and their $95 \%$ confidence limits, as well as Fisherian precision parameter $(k)$ estimates. Because the bias-correction is latitudedependent, this method produces slightly asymmetric confidence limits.

To calculate a mean paleomagnetic pole from azimuthally oriented samples, we first calculated virtual geomagnetic poles (VGP) from the ChRM directions from individual samples. We then combined the VGPs for samples from the same oriented core piece, since they are not independently oriented, and calculated a mean for each oriented piece using Fisher (1953) statistics. To estimate the mean pole position and its error limits, we used the maximum likelihood technique of Gordon and Cox (1980) because this method allows the combination of inclination-only and declination data. Furthermore, the method weights each measurement inversely by its errors and propagates the errors to determine a $95 \%$ confidence ellipse. Because few oriented pieces were available to work with, we analyzed inclination and declination separately, as the former could be defined with many more samples. This also allowed us to estimate the standard error associated with the orientation, so that it could be factored into the determination of pole location and confidence region. 
For an estimate of the azimuthal orientation error, we followed the procedure of Sager et al. (1994) and used the standard deviation of the oriented-piece declination means and subtracted the within-core-piece error, assumed to be represented on average by the standard deviation of piece-mean inclinations. This gave an average azimuthal orientation error that was added to the circular standard deviation for each oriented piece (the Fisherian $\alpha_{63}$ ) to derive a declination uncertainty. For inclination uncertainties, we assumed no orientation error and simply used $\alpha_{63}$ (see Sager et al., 1994). Because the uncertainty in two-dimensional (poles) and one-dimensional (inclination and declination) data, obtained from the same set of directions, are not equivalent, we corrected the inclination and declination error estimates to reflect our shift from two dimensions to one (Demarest, 1983).

\section{RESULTS}

\section{Magnetic Properties}

Most samples gave apparently reliable magnetic directions (Appendix). Of 165 samples, only 14 were magnetically unstable. Natural remanent magnetization (NRM) intensities were high for sediments and varied more than two and a half orders of magnitude, from 0.065 to $3.701 \mathrm{Am}^{-1}$ (Appendix). The strong NRM intensities evidently are the result of the abundant volcanic material contained in these sediments, and differences in magnitude likely reflect variations in the concentration of volcanic grains.

IRM acquisition curves (Fig. 2) showed rapid saturation in fields of less than 200 to $300 \mathrm{mT}$, a signature of titanomagnetite (e.g., McElhinny, 1973), implying that grains of this type are the principal magnetic carriers. On orthogonal vector plots, most samples displayed segments of apparent univectorial decay toward the origin, indicating that ChRM directions had been extracted (Fig. 3). The finer-grained samples, claystones and siltstones, typically gave more consistent directions and smaller MAD values than their coarsergrained counterparts, sandstones and siltstones (Fig. 3; Appendix). The amount and direction of overprint on each sample was variable, with some samples having little or none (Fig. 3, Samples 143-869B$36 \mathrm{R}-3,49-51 \mathrm{~cm}$ and $-57 \mathrm{R}-3,37-39 \mathrm{~cm})$ and some having large overprints (Fig. 3, Samples 143-869B-15R-2, 148-150 cm, -25R-3, $24-26 \mathrm{~cm}$, and $-39 \mathrm{R}-1-, 123-125 \mathrm{~cm})$. In addition, overprints were inconsistent in direction. Notably, two overprints often found in ODP cores, a Brunhes age normal polarity overprint and a vertical overprint caused by the drill string, were not significant in our samples.

\section{Paleoinclinations and Paleolatitude}

Most ChRM inclinations were negative (Appendix), and given age constraints, we assumed that these represent magnetizations acquired during or near the end of the Cretaceous Quiet Period at a site south of the equator. Samples in Cores 143-869B-22R to -26R and Section 143-869B-52R-2 gave mostly positive inclinations. We interpreted the former as a reversed polarity magnetic zone (see "Magnetic Polarity Stratigraphy") and the latter as a sedimentary disturbance (see "Discussion"). Four samples gave isolated positive inclinations (Appendix), probably owing to core pieces being inverted during handling.

Histograms of inclination absolute values show a large range from $1.2^{\circ}$ to $72.1^{\circ}$, with most values being between about $20^{\circ}$ and $40^{\circ}$ (Appendix and Fig. 4). A plot of inclination vs. depth showed a remarkable dichotomy of the inclinations by sedimentary units, with samples from Subunits IIIA, IIIB, IIIC, and IIIG giving an average about $10^{\circ}$ less than those from Subunits IIID, IIIE, and IIIF (Fig. 5). Each Inclination histogram constructed using this division showed a more peaked distribution, implying that the whole-population histogram contains two overlapping distributions (Fig. 4).

We divided the inclinations into two groups, based on lithologic subunit similarities, and calculated separate mean inclinations for
Subunits IIIA through IIIC, Subunit IIIG, and Subunits IIID through IIIF. The former yielded a mean of $-23.2^{\circ}$, with upper and lower $95 \%$ confidence limits of $19.9^{\circ}$ and $25.7^{\circ}$, respectively $(N=69 ; k=31)$. This corresponds to a paleolatitude of $12.1^{\circ} \mathrm{S}$ with confidence limits of $10.3^{\circ}$ and $13.5^{\circ}$. Subunits IIID through IIIF yielded a mean inclination of $-33.3^{\circ}$, with $95 \%$ confidence limits of $31.1^{\circ}$ and $35.0^{\circ}(N=60, k=$ 76 ), implying a paleolatitude of $18.2^{\circ} \mathrm{S}$ and confidence limits of $16.8^{\circ}$ and $19.3^{\circ}$. The 88 -Ma paleomagnetic pole for the Pacific Plate (Sager and Pringle, 1988) implies a paleolatitude of $21.4^{\circ} \mathrm{S} \pm 2.2^{\circ}$ for Site 869 , which is consistent with the result from Subunits IIID through IIIF, but not with that given by the other subunits (Fig. 6).

\section{Magnetic Polarity Stratigraphy}

Consistent positive paleoinclinations were found only in Cores 143-869B-22R to -26R, drilled from the lower Campanian part of Subunit IIIA, and from Section 143-869B-52R-2 of Cenomanian age (Subunit IIIE). Magnetic polarity zones were difficult to delineate in the Campanian section because of low recovery, because the cores typically contained small pieces that could become inverted during drilling or handling, and because many samples gave unreliable results (Appendix).

The top of a reversed polarity zone occurs at or near the top of Core 143-869B-22R. Although several samples gave apparently unreliable positive inclinations in Cores 143-869B-19R and -20R, Core 143-869B-22R appears to contain a switch from normal to reversed polarity (Fig. 7). Sample 143-869B-22R, 115-117 cm, gave an apparently reliable negative inclination, as did the two samples above it from Core 143-869B-20R. Directly below this, three of four samples in Core 143-869B-22R gave positive inclinations, implying reversed polarity. The single negative-inclination sample yielded a MAD of $8.0^{\circ}$, suggesting that this inclination may not be reliable. Thus, we prefer an interpretation in which most of the material from Core $143-869 \mathrm{~B}-22 \mathrm{R}$ is reversely polarized, except perhaps at the very top. If the uppermost sample from Core 143-869B-22R is not inverted, then the top of the reversal is within the core; otherwise, it occurs between this core and the one above.

All of the samples measured from Cores 143-869B-25R and -26R are reversely polarized (Appendix), but whether the reversal in Core $143-869 \mathrm{~B}-22 \mathrm{R}$ extends down to this level is uncertain, as is the location of the bottom of this reversed-polarity zone. Two of three samples in Core 143-869B-23R appear to be normally polarized, but the third, which appears to be reversely polarized, has a ChRM defined with only three points and with a large MAD (6.3 ${ }^{\circ}$; Appendix). Consequently, it seems that Core 143-869B-23R contains normally polarized material separating the reversed-polarity interval into two sections. The bottom of the lower reversed-polarity zone is illdefined because of poor recovery in Cores 143-869B-27R to -30R. Sample 143-869B-27R-1, 62-64 cm is the only one from $28.9 \mathrm{~m}$ of cored section and it gave a negative inclination, implying normal polarity. Samples in Core 143-869B-30R and below give normal, negative inclinations (Fig. 7). We interpret the bottom of the reversedpolarity zone to be between Cores 143-869B-26R and -27R, on the basis of the one sample in the latter and because the bottom of Subunit IIIA occurs at the same depth (Sager, Winterer, Firth, et al., 1993) and implies a change in sedimentation that could contain a time gap.

Deeper in the hole, in the Cenomanian section, a zone exists within Section 143-869B-52R-2 that also contains positive inclinations (Appendix). It was discovered because this section contains the contact at the base of a breccia layer, which was identified in the FMS log, so we sampled the claystones just below it to attempt to reorient them. The five samples in this section all give positive inclinations (Appendix), but unfortunately, the corrected declinations were near $270^{\circ}$, so we could not confirm the polarity by their values. For reasons discussed below, we think that the positive inclinations resulted from disturbance owing to the deposition of the breccia. 


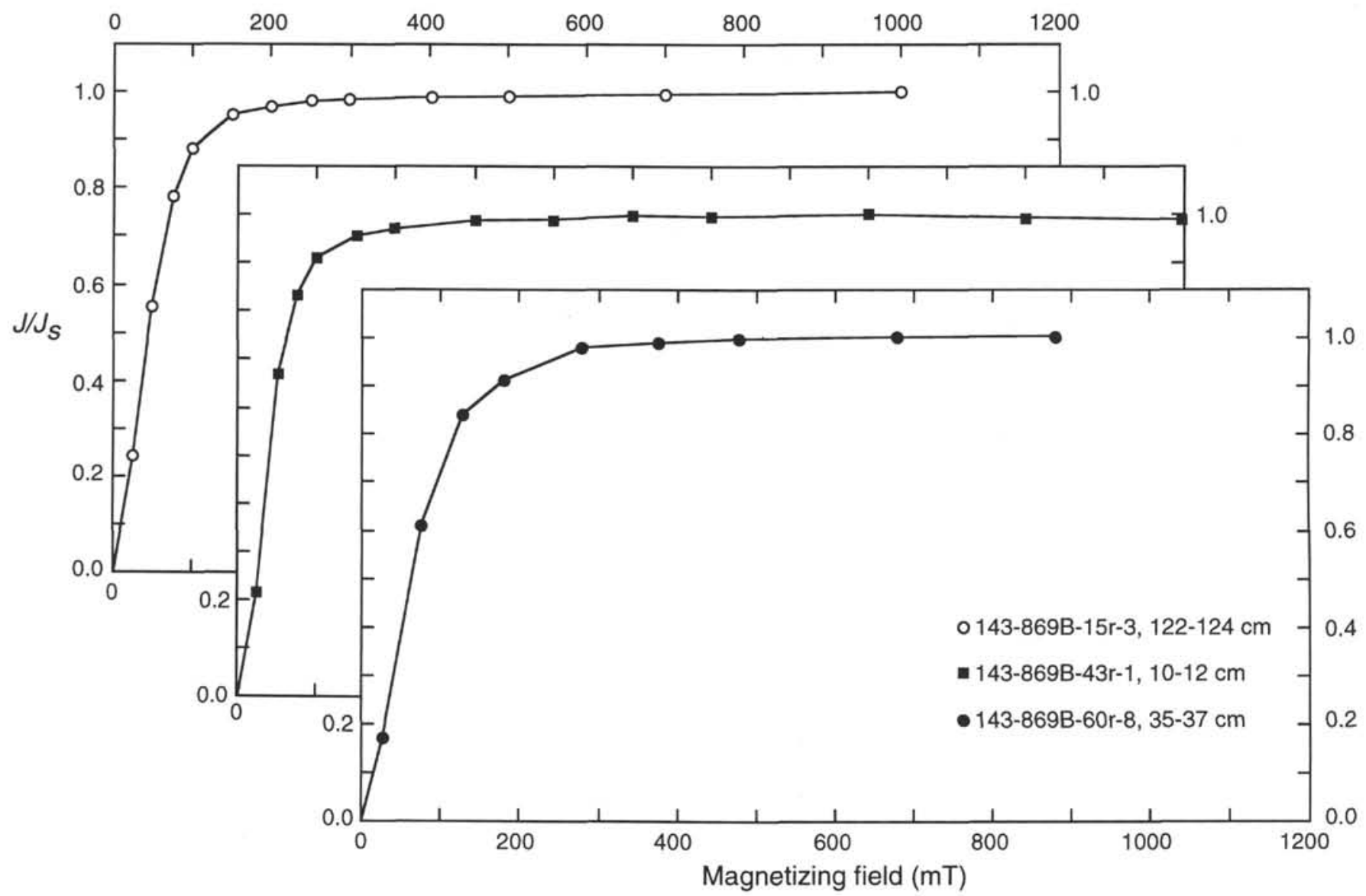

Figure 2. Isothermal remanent magnetization (IRM) acquisition curves for three representative samples from Hole 869B. Samples 143-869B-15R-3, 122-124 cm, and $-60 \mathrm{R}-8,35-37 \mathrm{~cm}$, are claystones, whereas $143-869 \mathrm{~B}-43 \mathrm{R}-1,10-12 \mathrm{~cm}$, is a coarse volcaniclastic sediment.

\section{Azimuthally Oriented Paleomagnetic Pole}

In all, only 15 features suitable for orientation were correlated from FMS log to core. These consisted of seven dipping brecciaclaystone contacts, five individual beds, and three zones of steeply dipping sandstone beds. Of these, we rejected the results from seven features as unreliable because they did not give reasonable declination values (i.e., within $\pm 90^{\circ}$ of north). Values outside this range were considered to be unreliable because we know that Cretaceous paleomagnetic poles for the Pacific Plate are located in the North Atlantic (Sager and Pringle, 1988), so the expected declination is near zero. Apparently reliable declination corrections were given by eight features: three contacts, two individual layers, and three sections of core in which steeply dipping sandstone layers could be matched with similar dips in the FMS logs (Table 1). Of the seven features that gave unreliable declination corrections, four were breccia/claystone contacts. In the next section, we will argue that such breccias may be the cause of unreliable magnetic directions in underlying sediments.

Each of the eight oriented features (Table 1) was used to correct the declinations of two to four individual samples (Table 2). The VGPs calculated from the means of these samples are scattered mainly in a direction nearly perpendicular to a great circle that connects the site and the north pole (Fig. 8). This is a result of the uncertainty inherent in the azimuthal orientations of the core features. The mean declinations of the sample groups ranged from $-38.1^{\circ}$ to $30.8^{\circ}$ and had variable precisions, with $\alpha_{63}$ values from $2.0^{\circ}$ to $63.5^{\circ}$ (Table 2). The standard deviation of declinations was $22.8^{\circ}$ and that for inclinations was $4.3^{\circ}$, so we calculated an orientation standard error of $22.4^{\circ}$ (see Sager et al., 1994). Using this value, the estimated declination standard errors ranged from $22.6^{\circ}$ to $51.4^{\circ}$, depending on the precision of each mean direction (Table 2).

Using a maximum-likelihood method (Gordon and Cox, 1980), we calculated a mean pole location of $60.8^{\circ} \mathrm{N}, 347.3^{\circ} \mathrm{E}$ with a $95 \%$ confidence ellipse having major and minor semiaxis lengths of $21.2^{\circ}$ and $4.9^{\circ}$, respectively, with the former oriented $93^{\circ}$ clockwise from north (Fig. 8). This pole lies near the mid- to Late Cretaceous part of the Pacific apparent polar wander path, but has a large uncertainty along the polar path owing to the uncertainty in declination observations. Data "importance" values (Gordon and Cox, 1980) from the pole calculation showed that the co-latitude calculated from sample inclinations constrains the pole location entirely in one dimension (distance from site to pole), as expected. Most of the declination values constrain $10 \%$ to $15 \%$ of the other direction (pole azimuth), except for the feature $\mathrm{C}$ declination which has a low importance (3\%) because of its large standard error. A reduced $\chi^{2}$ statistic derived from the misfits of the pole and observational data had a value of 0.7 , falling between $95 \%$ confidence limits $(0.31,2.0)$ for a $\chi^{2}$ variable with seven degrees of freedom. This indicates that the error values used for the data (and propagated into confidence limits) are consistent with the observed data scatter (Gordon and Cox, 1980).

\section{DISCUSSION}

\section{Reliability of Magnetic Directions}

Most of the samples examined in this study gave demagnetization sequences that implied that stable ChRM directions had been isolated. This is evident in the generally low MAD values for most samples (Appendix). The 14 samples that did not yield stable directions were 
143-869B-36R-3, 49-51 cm

Claystone

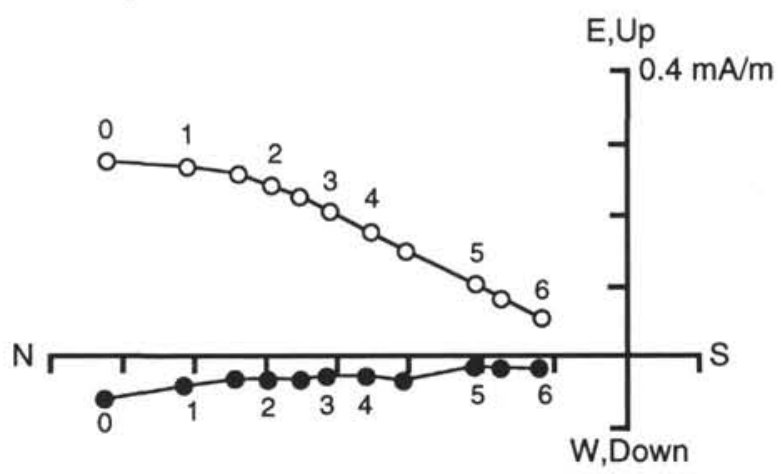

143-869B-25R-3, 24-26 cm

Siltstone

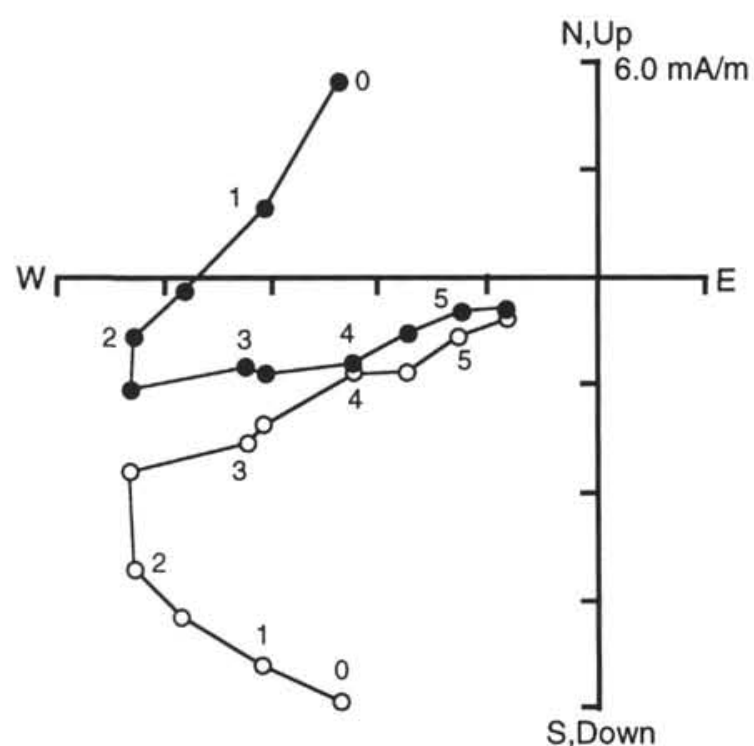

143-869B-36R-4, 27-29 cm

Claystone

AF

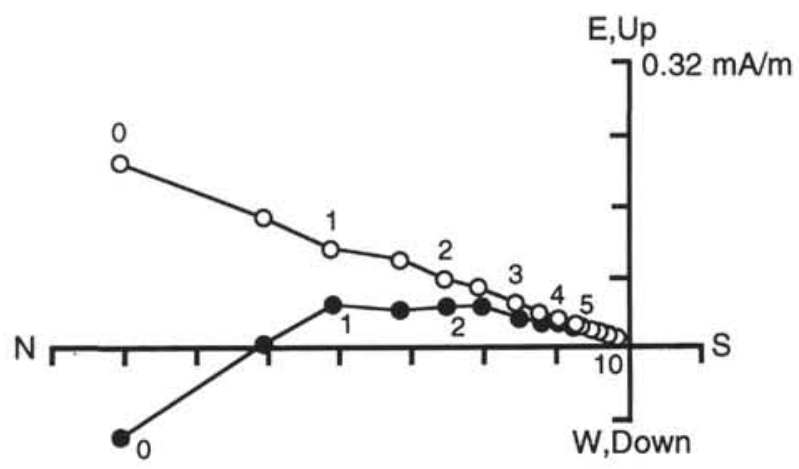

143-869B-57R-3, $37-39 \mathrm{~cm}$

Siltstone

$\mathrm{TH}$

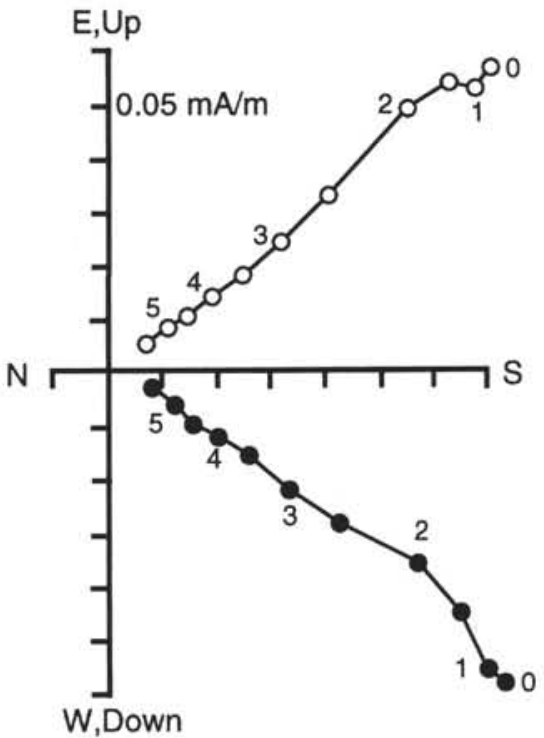

- Horizontal

○ Vertical

Figure 3. Representative orthogonal vector ("Zijderveld") plots of sample magnetizations during stepwise AF and thermal demagnetization. Two examples each of claystones, siltstones, sandstones, and coarse volcaniclastics are shown. Numbers along the demagnetization paths give the $\mathrm{AF}$ field strength (in tens of milliteslas) or the temperature (in hundreds of degrees Celsius).

Table 1. FMS/core feature orientation data.

\begin{tabular}{|c|c|c|c|c|c|c|c|c|c|}
\hline \multirow[b]{2}{*}{ Feature } & \multirow[b]{2}{*}{ Type } & \multicolumn{3}{|c|}{ FMS Log } & \multicolumn{4}{|c|}{ Core } & \multirow[b]{2}{*}{$\begin{array}{l}\text { Decl. } \\
\text { corr. }\end{array}$} \\
\hline & & $\begin{array}{l}\text { Log depth } \\
\text { (mbsf) }\end{array}$ & $\begin{array}{l}\text { Dip } \\
\left({ }^{\circ}\right)\end{array}$ & $\begin{array}{l}\text { Dir. } \\
\left({ }^{\circ}\right)\end{array}$ & $\begin{array}{l}\text { Core, section, } \\
\text { interval }(\mathrm{cm})\end{array}$ & $\begin{array}{l}\text { Depth } \\
\text { (mbsf) }\end{array}$ & $\begin{array}{l}\text { Dip } \\
\left({ }^{\circ}\right)\end{array}$ & $\begin{array}{l}\text { Dir. } \\
\left({ }^{\circ}\right)\end{array}$ & \\
\hline $\begin{array}{c}143-869 \mathrm{~B} \\
\mathrm{~A}\end{array}$ & B & $557-558$ & 44.8 & 66.0 & $45 \mathrm{R}-3,75$ & 553.05 & 42.6 & 26.2 & 39.8 \\
\hline B & B & $558-559$ & 40.4 & 74.0 & $45 \mathrm{R}-4,12$ & 559.9 & 40.5 & 35.7 & 38.3 \\
\hline C & C & 605.7 & 19.7 & 344.0 & $50 \mathrm{R}-1,110$ & 605.3 & 34.3 & 105.2 & 238.0 \\
\hline D & B & 634.2 & 59.5 & 102.0 & $53 \mathrm{R}-3,118$ & 636.08 & 28.7 & 223.5 & -121.5 \\
\hline E & L & 654.7 & 4.8 & 43.0 & $55 \mathrm{R}-2,40$ & 653.4 & 2.8 & 225.0 & -182.0 \\
\hline F & L & 671.5 & 6.9 & 53.0 & $57 \mathrm{R}-1,54$ & 671.5 & 4.5 & 63.5 & -10.5 \\
\hline G & C & 673.8 & 4.4 & 81.0 & $57 \mathrm{R}-2,125$ & 673.45 & 19.3 & 20.7 & 60.3 \\
\hline $\mathrm{H}$ & $\mathrm{C}$ & 689.7 & 8.1 & 340.0 & $59 \mathrm{R}-1,25$ & 690.25 & 18.5 & 215.9 & 124.1 \\
\hline
\end{tabular}

Notes: Type $=$ type of feature with $\mathrm{B}=$ bedding (more than one layer), $\mathrm{C}=$ contact at base of volcaniclastic layer and $\mathrm{L}=\operatorname{single}$ layer; Dip $=$ dip angle of feature below horizontal (in degrees). FMS log dip, dir. = dip and downdip direction of feature in FMS log, relative to geographic north (in degrees). Core dip, dir. = downdip direction of feature relative to core coordinates, positive clockwise from direction perpendicular to the split face (in degrees). Decl. corr, = declination correction (degrees), defined as FMS feature dip direction minus core feature dip direction. This value is added to sample declination to correct it to geographic coordinates. 
143-869B-15R-2, 148-150 cm
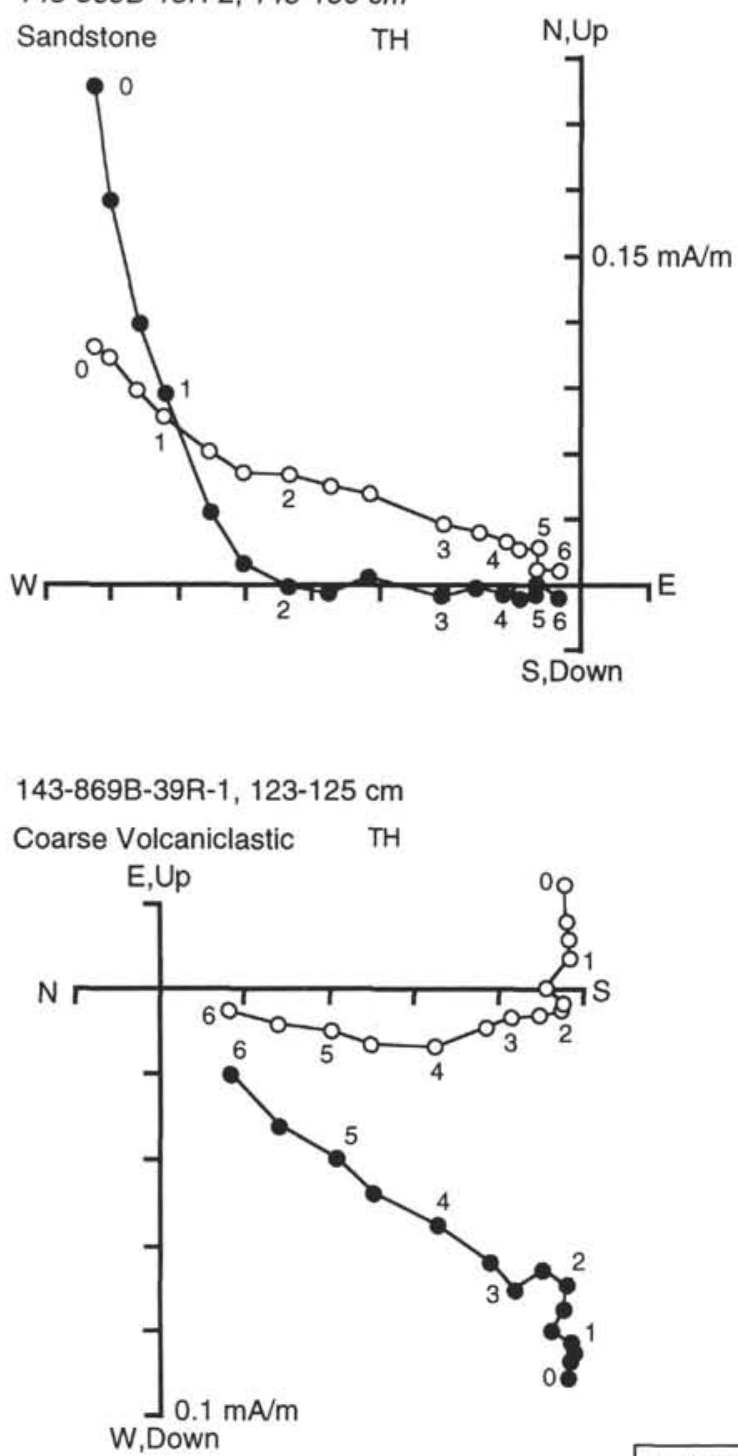

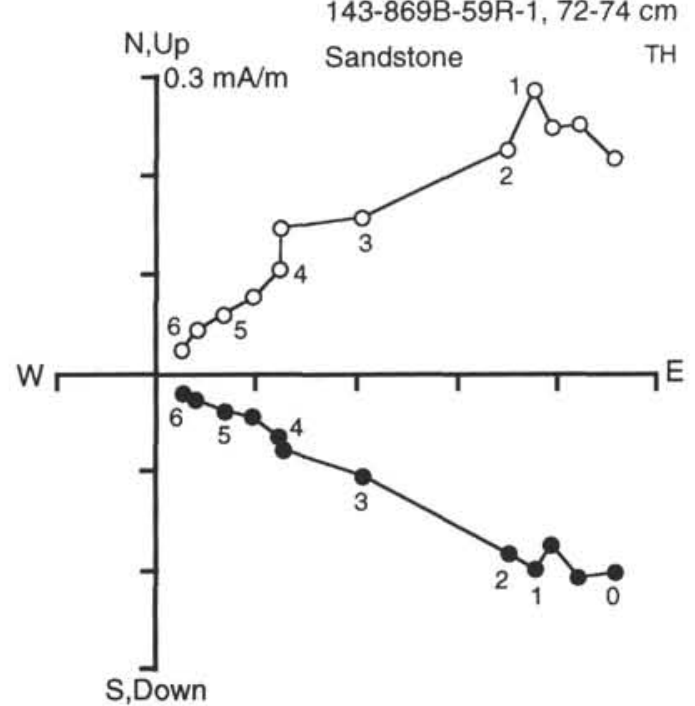

143-869B-41R-2, 88-90 cm

Coarse Volcaniclastic AF

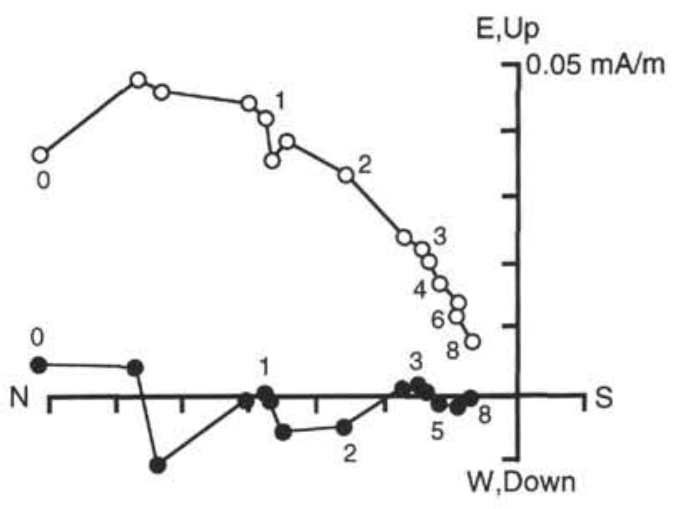

- Horizontal

○ Vertical

Figure 3 (continued).

coarse-grained sandstones or coarser volcaniclastics (Appendix). Such sediments may contain large, unstable magnetic grains or they may contain grains, such as basalt clasts in the breccias, that have magnetizations that are randomized by the process of deposition. Claystones and siltstones, in contrast, almost always gave demagnetization sequences having little scatter (Fig. 3), implying that the directions are reliably determined.

Nevertheless, the population of paleoinclinations showed two distinct means, $-23.2^{\circ}$ and $-33.3^{\circ}$, the former value being significantly different from the $-38.1^{\circ}$ that is inferred from the 88 -Ma Pacific paleomagnetic pole (Fig. 6). This shallow inclination cannot be explained by polar wander, because early Late Cretaceous polar motion would have caused a change in declination only (Sager and Pringle, 1988). Instead, it appears that the shallower inclination is biased. Similar shallow inclinations have been noted in other Pacific drill-core paleomagnetic data (Gordon, 1990; Tarduno, 1990; Steiner and Wallick, 1992), particularly in older, consolidated sediments. The reasons for inclination-shallowing are poorly understood, but grain-rotation during compaction is a widely accepted explanation. The magnetic grains may be elongated so that vertical shortening during compaction causes them to rotate toward the horizontal (King, 1955; Blow and Hamilton, 1978), or small magnetic grains may adhere to clay particles that have been rotated toward the horizontal (Anson and Kodama, 1987).

Deciphering the mechanism of inclination-shallowing is beyond the scope of this study; nevertheless, our data give some interesting clues. Age does not seem to be the controlling factor because shallowed inclinations were found in sediments of both Cenomanian (Subunit IIIG) and post-Cenomanian (Subunits IIIA-IIIC) age. Furthermore, the shallowing does not appear to be a function of burial depth because the shallowed inclinations were found at the bottom as well as the top of the hole, with apparently unshallowed inclinations between (Fig. 5). Because the sedimentary units that gave shallow inclinations are rich in claystones and those that gave apparently reliable inclinations are mostly siltstones, sandstones, and coarser volcaniclastics, it could be argued that lithology, in particular the presence of clay, is a prime factor. However, inclination histograms based on sediment type did not divide the samples as neatly into 

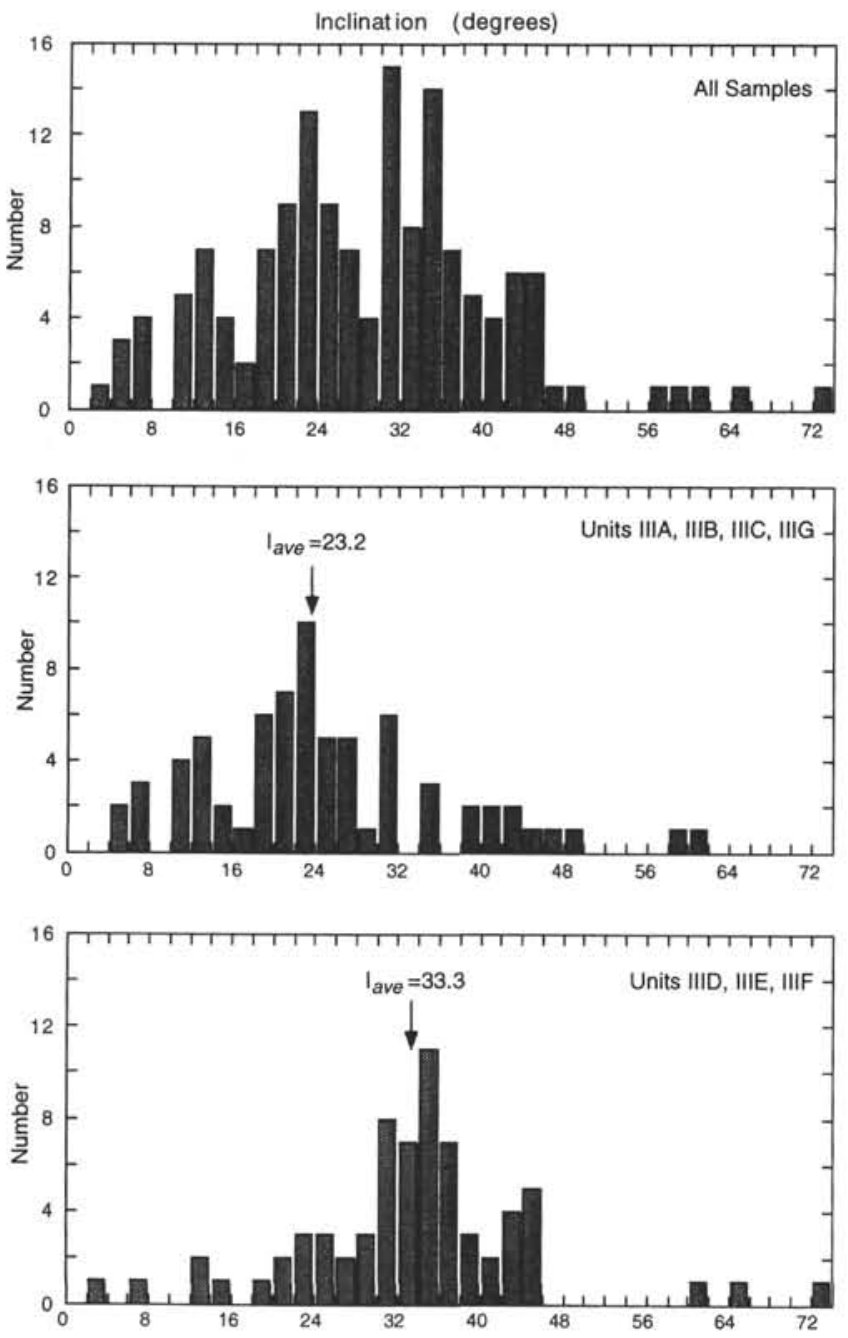
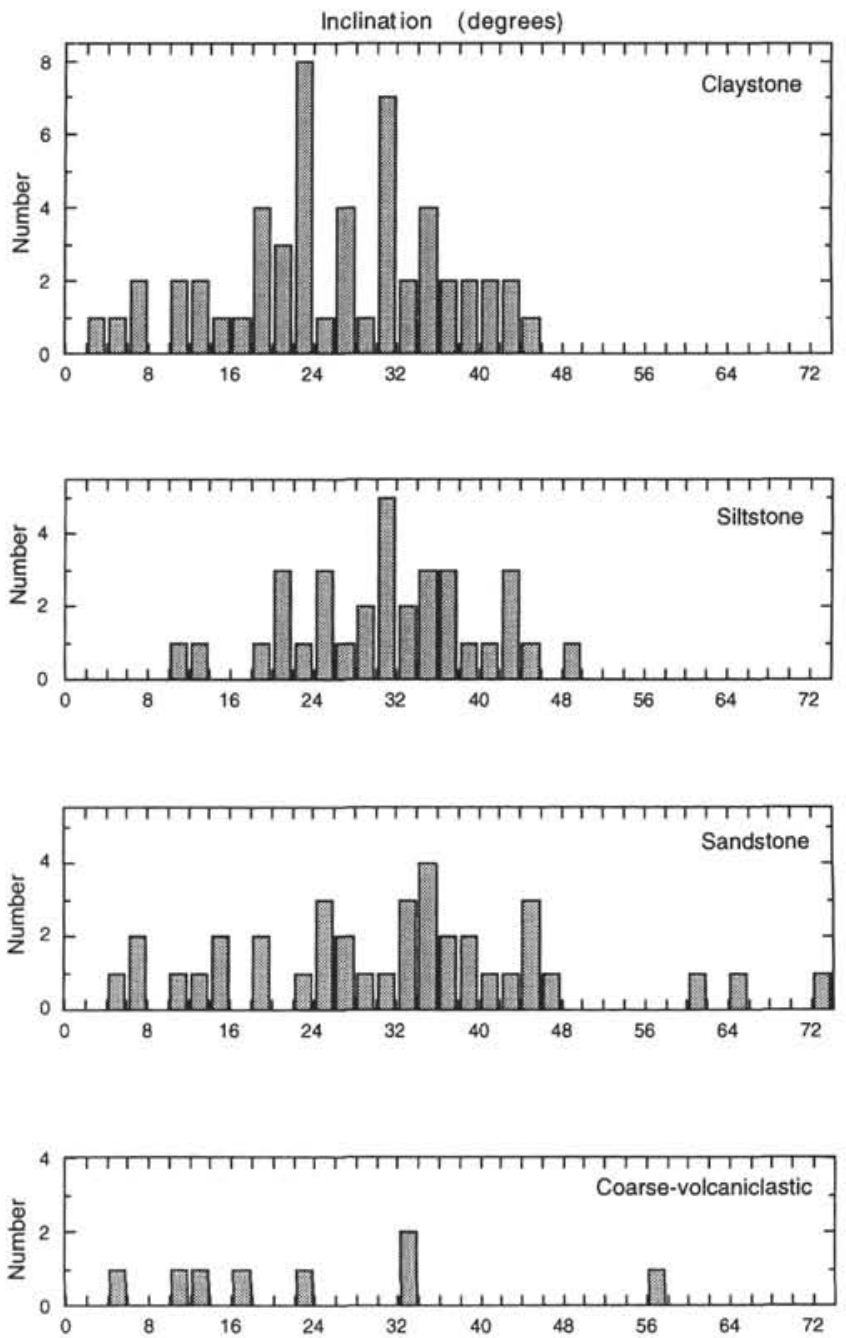

Figure 4. Histograms of sample inclination absolute values. Frequency of occurrence is shown on the vertical axis vs. inclination on the horizontal axis. A histogram for all stable samples is shown at the upper left; other histograms show distributions for various sample groups based on lithologic subunits (left) and sediment type (right).

inclination groups, as did a simple division based on lithologic unit boundaries. This may be due in part to the fact that the Site 869 sediments are often poorly sorted; indeed, many samples classified, for example, as "sandstone" contain a significant fraction of clay as well. Thus, general sediment type does not seem to be the dominant factor constraining shallowing. Although it is not obvious why it would give rise to a difference in inclination bias, the greatest difference between the sediments having apparently shallowed inclinations and those with unshallowed inclinations seems to be sedimentation rate and style. The Cenomanian sediments, except those of Subunit IIIG, were deposited much more rapidly than the post-Cenomanian sediments. Furthermore, the post-Cenomanian sediments were deposited as thin turbidites, whereas the Cenomanian sediments (except Subunit IIIG) were deposited as thick turbidites.

Results using the FMS to provide azimuthal orientation for pieces of core were disappointing as the standard deviation of reoriented declinations was $22.8^{\circ}$. Consequently, the paleomagnetic pole calculated from these values has a large uncertainty in the direction constrained by declination (Fig. 8). Several problems led to difficulties when determining orientation corrections. Few features had dips sufficiently steep for reliable orientation ( $>5^{\circ}$, MacLeod et al., 1994), and dipping features did not have consistent directions; thus, features had to be correlated from log to core on a 1:1 basis. Few such features could be found, and some were poorly preserved. As a consequence, we found only about 15 pieces of core that we could attempt to orient. Some of these features gave orientation corrections that obviously were flawed. We think this arose from two problems, both a consequence of the fact that many of these features are erosional contacts between breccia units and underlying claystones. First, although they appear planar in the logs, many contacts showed small-scale irregularities that made it difficult to obtain a reliable measurement of the orientation within the cores. Second, magnetic directions in claystones directly beneath thick breccia units sometimes seemed to be more scattered than elsewhere, implying some sort of sediment disturbance. A notable example is an apparent reversal of inclinations in Section 143-869B-52R-2. This section and the next are contiguous, except at the section break (see photo in Sager, Winterer, Firth, et al., 1993, p. 669). A breccia-base contact occurs at a depth of $50 \mathrm{~cm}$ in Section 143-869B-52R-2, and samples below the contact in the remainder of the section give positive inclinations with a wide scatter from $2.1^{\circ}$ to $44.1^{\circ}$ (Appendix).

Because it is thought that no reversals occurred in the Cenomanian (Tarduno et al., 1992) and because the inclinations are scattered, but return to more normal behavior in Section 143-869B-52R-3, it seems most likely that the deposition of the breccia, over 6-m thick, not only eroded some sediment to produce the dipping contact but also dis- 


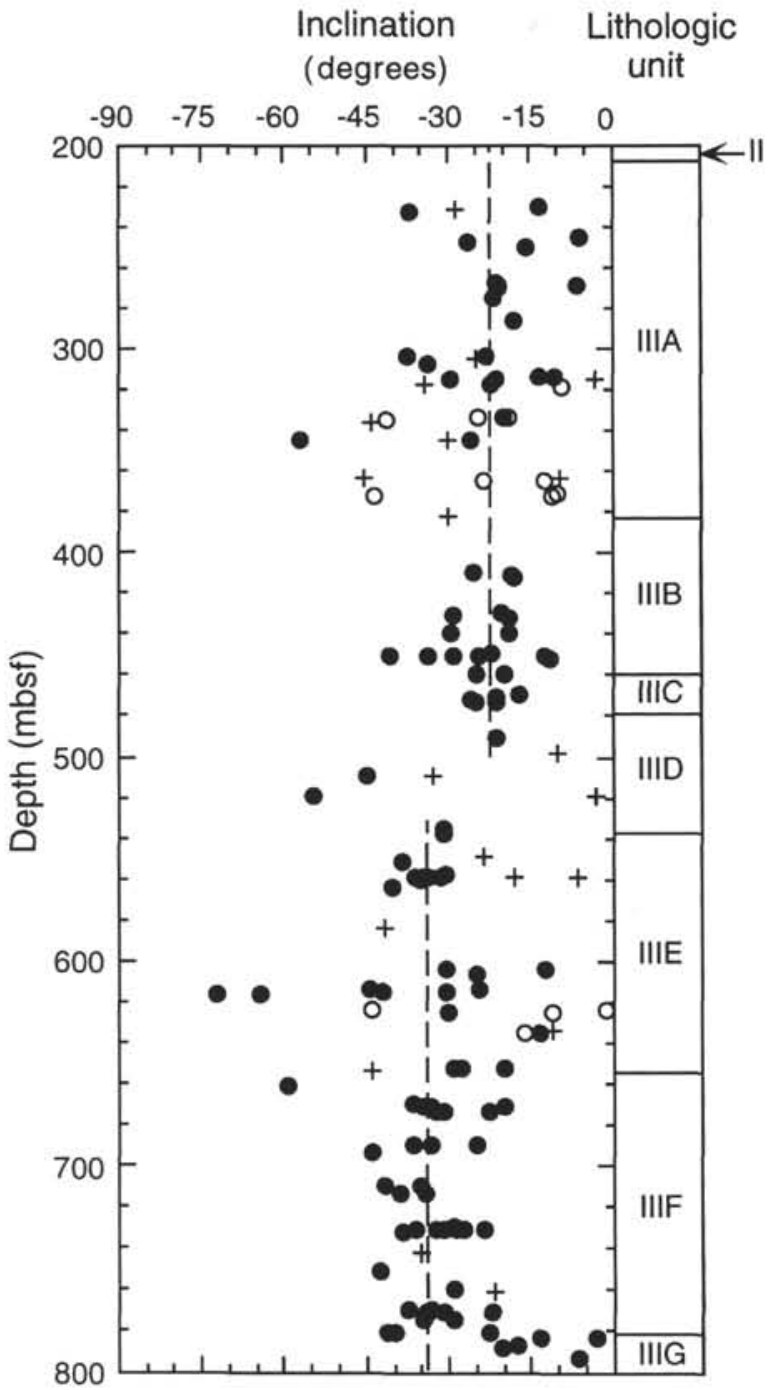

Figure 5. Inclination values plotted vs. depth, Hole 869B. Open and solid circles show the most reliable sample inclinations, whereas crosses denote less reliable results. Open circles represent positive inclinations, whose negative values were plotted for easier comparison. Sedimentary units and subunits (from Sager, Winterer, Firth, et al., 1993) are plotted on the right side of the column.

turbed the sediments in the meter beneath the contact. The manner of disturbance is unclear because no obvious mechanical disruption of these sediments was observed in the core. If the disturbance was not mechanical, an alternative hypothesis is that the magnetization of these sediments was not yet locked when the breccia was deposited and the sediments recorded a perturbed magnetic field in proximity to the relatively strongly magnetic breccia.

\section{Paleolatitude and Paleopole}

The paleolatitude of $18.2^{\circ} \mathrm{S}\left(95 \%\right.$ confidence limits, $16.8^{\circ}$ to $19.2^{\circ} \mathrm{S}$ ), derived from Cenomanian Subunit IIID-IIIF sediments, is consistent with that implied by the 88 -Ma Pacific paleomagnetic pole (Fig. 6). This particular paleomagnetic pole is constrained almost entirely by inversions of magnetic anomalies over seamounts (Sager and Pringle, 1988), which may be biased by induced or viscous magnetization (Hildebrand and Staudigel, 1986; Gee et al., 1989; 1993). Because all of the seamounts used for this pole are normally polarized, such a bias would lead to an "inclination-shallowing" sim-

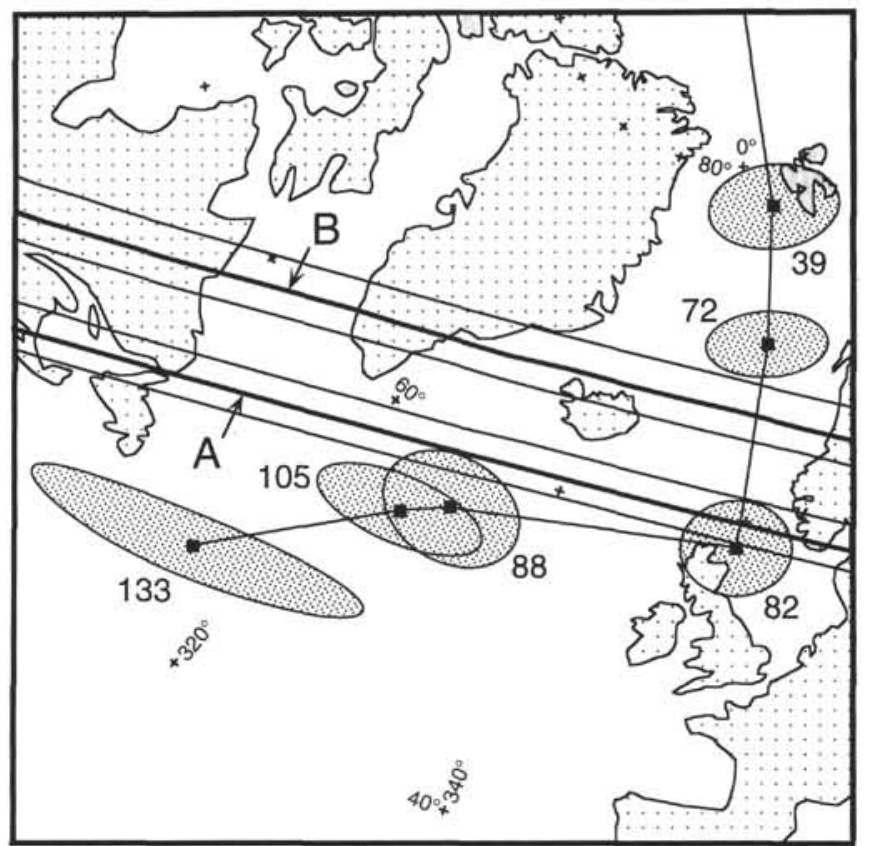

Figure 6. Comparison of paleocolatitudes, calculated from mean sample inclinations, with the Pacific apparent polar wander path. The thick arc labeled " $A$ " shows the co-latitude derived from Cenomanian lithologic Subunits IIID through IIIF; that labeled " $\mathrm{B}$ " shows the co-latitude from post-Cenomanian Subunits IIIA to IIIC and Cenomanian Subunit IIIG. The thin arcs on either side of the co-latitude arcs show $95 \%$ confidence limits. Solid squares connected by a thin line denote paleomagnetic poles on the Pacific apparent polar wander path. They are encircled by stippled ellipses representing their $95 \%$ confidence regions and are labeled by mean age in millions of years. The 105-Ma pole is discussed in Winterer and Sager (this volume); the others are from Sager and Pringle (1988). The plot is a polar equal area map of the northern Atlantic showing continental outlines for reference.

ilar to that which can occur for sediments. The agreement of the seamount with sediment data is encouraging because even though both may be biased by similar amounts, a simpler explanation is that the agreement indicates both have minimal bias. Nevertheless, we should interpret the sediment paleolatitude as a minimum estimate. This paleolatitude implies that the Pikinni-Wodejebato edifice was within the tropics, albeit near the southern limit, during the Cenomanian.

The oriented paleomagnetic pole, located at $60.8^{\circ} \mathrm{N}, 347.3^{\circ} \mathrm{E}$ has a Cenomanian biostratigraphic age (Fig. 1) and a maximum age of $96.6 \pm 0.8 \mathrm{Ma}$ (Pringle and Duncan, this volume) from a radiometrically dated basalt clast. This pole is also consistent with the Late Cretaceous portion of the Pacific apparent polar wander path (Fig. 8). Because of the great uncertainty in the azimuthal orientation of samples, the $95 \%$ confidence ellipse has a long major axis $\left(21.2^{\circ}\right)$ that is aligned along the polar wander path. Unfortunately, this pole does provide much constraint on the longitude of the Cenomanian point on the polar path.

\section{Magnetic Polarity Stratigraphy}

It is not surprising that Hole $869 \mathrm{~B}$ samples are predominantly normally polarized, because the geomagnetic field was in this state during much of the Late Cretaceous, which included the Cretaceous Quiet Period, a period of approximately $35 \mathrm{~m} . \mathrm{y}$. that had few magnetic reversals (Harland et al., 1990; Tarduno et al., 1992). Microfossils indicate that the lower part of Subunit IIIA is Campanian in age, specifically, late early Campanian in Cores 143-869B-18R to -19R and mid- to early Campanian in Cores 143-869B-23R to -28R (J. 


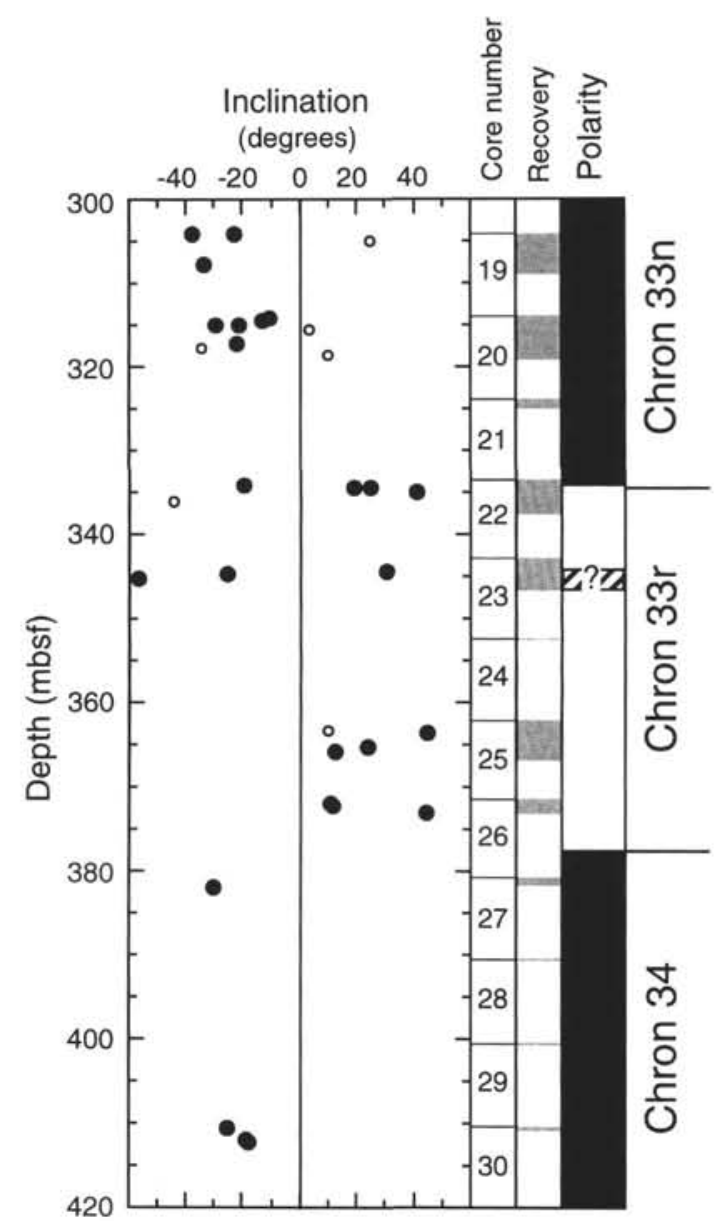

Figure 7. Interpreted magnetic polarity stratigraphy, Hole 869B. Sample inclinations are plotted on the horizontal axis vs. depth on the vertical axis. Solid circles show reliable inclinations, whereas small, open circles denote less reliable samples. Core numbers and recovery are shown outside the right side of the inclination column; stippled zones represent recovered core (note: ODP convention places all recovered core at the top of the drilled interval). At right is a magnetic polarity interpretation; black represents normal polarity and white, reversed polarity. The hatched zone represents a possible magnetic excursion, analogous to that reported from Site 462 (Steiner, 1983).

Mütterlose, pers. comm., 1993). Thus, the reversed-polarity section is most likely Chron 33R, which occupies the bottom of the Campanian in most geomagnetic polarity reversal time scales (Harland et al., 1990; Cande and Kent, 1992).

If we interpret the upper reversed-polarity section as Chron $32 \mathrm{R}$, the next reversed-polarity interval above Chron $33 \mathrm{R}$, we have a problem. Chron 32R occurred more than $6 \mathrm{~m}$.y. later than Chron 33R and it is considered to be within the lowermost Maastrichtian (Harland et al., 1990). In Hole 869B, the Maastrichtian-Campanian boundary occurs well above the reversed section, at about the level of Cores 143-869B-8R to -10R (J. Mütterlose, pers. comm., 1993), so it seems unlikely that this is Chron $32 \mathrm{R}$.

The positive inclinations from Core 143-869B-23R, from the upper part of the reversed polarity section interpreted to be Chron $33 \mathrm{R}$, are a problem because in accepted time scales this chron does not contain a normal polarity interval (e.g., Cande and Kent, 1992). Thus, these positive inclinations probably do not indicate a polarity reversal. On the other hand, similar positive inclinations were observed at about the same level within Chron 33R cored at two holes at Site 462 (Steiner, 1983), located $420 \mathrm{~km}$ to the south, in the Nauru Basin. Because the inclination reversal has not been observed glob- ally, it was suggested that this feature is a magnetic excursion, possibly local in its extent (Steiner, 1983). Thus, our observation of the same feature implies that our samples provide a reliable inclination record and that the observations at Site 462 were also accurate.

Although several samples in Core 143-869B-52R gave positive inclinations, implying a reversed polarity, we do not think that these samples represent a true magnetic polarity reversal. It is possible that short, undiscovered reversals occurred within the Cenomanian, but none have been found that can be correlated globally (Tarduno et al., 1992). The observation that these samples are from claystone just below a thick breccia layer and that their inclinations are more scattered than expected for this lithology, lead us to postulate that the apparent reversal is the result of some form of sediment disturbance.

\section{CONCLUSIONS}

Almost all samples measured in this study gave negative inclinations, implying normal-polarity magnetizations acquired in the Southern Hemisphere. We found two reversed polarity zones, shown by positive inclinations, in Cores $143-869 \mathrm{~B}-22 \mathrm{R}$ and $-24 \mathrm{R}$ to $-26 \mathrm{R}$, but think these represent only one reversed-polarity period, Chron $33 \mathrm{R}$. We cannot interpret the upper reversed zone as the next younger reversal without an unreasonable conflict with the biostratigraphy, so we think that the apparently normal zone in between is the same local "excursion" observed at the equivalent magnetostratigraphic level at nearby Site 462 (Steiner, 1983). A short, 1-m-long apparent reversedpolarity zone occurs in Section 143-869B-52R-2, but the samples in this interval occur immediately beneath a 6 -m thick breccia layer and have inclinations more scattered than expected. We hypothesize that the apparent reversal is a result of the breccia emplacement: either the sediments were mechanically disturbed or the breccia perturbed the magnetic field in its proximity owing to its content of highly magnetic volcanic fragments.

Inclination values from Hole 869B samples fell into two groups, with bias-corrected mean inclinations of $-23.2^{\circ}$ (95\% confidence limits: $19.9^{\circ}, 25.7^{\circ} ; N=69$ ) and $-33.3^{\circ}$ (95\% confidence limits: $31.1^{\circ}, 35.0^{\circ} ; N=60$ ). The steeper inclination is consistent with the 88-Ma Pacific paleomagnetic pole, derived mainly from seamount magnetic anomaly inversions (Sager and Pringle, 1988). This inclination implies that Site 869 was at $18.2^{\circ} \mathrm{S}$ ( $95 \%$ confidence limits: $16.8^{\circ}, 19.2^{\circ}$ ), near the southern limit of the tropics, during the Cenomanian. The shallower inclination is significantly different and this difference cannot be explained by tectonics or polar wander. Therefore, we conclude that this value is affected by "inclinationshallowing," a bias that seems to be common in Pacific drill-core paleomagnetic data from sediments (Tarduno, 1990). The clearest division of the samples into the two inclination groups was made along lithologic unit boundaries. Subunits IIIA, IIIB, IIIC, and IIIG gave shallow inclinations, whereas Subunits IIID, IIIE, and IIIF gave steeper inclinations. The main difference between these unit groupings is rate and style of deposition. Shallow inclinations were given by units deposited as thin turbidites, whereas the steeper inclinations were given by units deposited more rapidly as thick turbidites. Lithology may also play a role, because the shallow-inclination units have greater amounts of clays as compared to volcaniclastic silts, sands, and breccias in the other units; however, a division by sediment type did not separate the inclinations into the two groups as neatly.

Owing to difficulties when correlating FMS log and core features, only eight core segments could be azimuthally oriented. These had mean declinations that ranged from $-38.1^{\circ}$ to $30.8^{\circ}$ and a standard deviation of $22.8^{\circ}$. Combining these declinations with the steeper mean inclination, we calculated an azimuthally oriented Cenomanian paleomagnetic pole at $60.8^{\circ} \mathrm{N}, 347.3^{\circ} \mathrm{E}$, with a $95 \%$ confidence ellipse having major and minor semiaxes of $21.2^{\circ}$ and $4.9^{\circ}$, the former trending $93^{\circ}$. This pole is located along the Late Cretaceous portion of the Pacific apparent polar wander path, in agreement with the 88-Ma paleomagnetic pole (Sager and Pringle, 1988). 
Table 2. Oriented sample data from Hole 869B.

\begin{tabular}{|c|c|c|c|c|c|c|c|c|c|c|}
\hline \multirow[b]{2}{*}{ Feature } & \multirow[b]{2}{*}{$\begin{array}{l}\text { Core, section, } \\
\text { interval }(\mathrm{cm})\end{array}$} & \multirow[b]{2}{*}{$\begin{array}{l}\text { Incl. } \\
\left({ }^{\circ}\right)\end{array}$} & \multirow[b]{2}{*}{$\begin{array}{c}\text { Decl. } \\
\left({ }^{\circ}\right)\end{array}$} & \multirow[b]{2}{*}{$\begin{array}{l}\text { Decl. } \\
\text { corr. }\end{array}$} & \multicolumn{2}{|c|}{ Paleopole } & \multirow{2}{*}{$\begin{array}{l}\text { Ave. } \\
\text { decl. } \\
\left({ }^{\circ}\right)\end{array}$} & \multirow[b]{2}{*}{$\begin{array}{l}\alpha_{63} \\
\left(^{\circ}\right)\end{array}$} & \multirow[b]{2}{*}{$k$} & \multirow[b]{2}{*}{$\begin{array}{l}S_{d} \\
\left({ }^{\circ}\right)\end{array}$} \\
\hline & & & & & $\begin{array}{l}\text { Lat. } \\
\left({ }^{\circ} \mathrm{N}\right)\end{array}$ & $\begin{array}{l}\text { Long. } \\
\left({ }^{\circ} \mathrm{E}\right)\end{array}$ & & & & \\
\hline \multirow[t]{4}{*}{ A } & $45 R-3,64-66$ & -30.6 & 314.3 & 354.1 & & & & & & \\
\hline & $45 R-3,76-78$ & -31.8 & 308.0 & 347.8 & & & & & & \\
\hline & $45 R-3,105-107$ & -34.0 & 307.2 & 347.0 & & & & & & \\
\hline & $45 \mathrm{R}-3,110-112$ & -36.0 & 309.1 & 348.9 & 59.1 & 4.5 & -10.5 & 2.0 & 563 & 22.6 \\
\hline \multirow[t]{3}{*}{ B } & $45 R-4,11-13$ & -34.9 & 325.6 & 3.9 & & & & & & \\
\hline & $45 R-4,22-24$ & -6.4 & 346.5 & 24.8 & & & & & & \\
\hline & $45 \mathrm{R}-4,27-29$ & -18.0 & 351.1 & 29.4 & 60.8 & 302.1 & 19.7 & 12.0 & 27 & 24.2 \\
\hline \multirow[t]{2}{*}{$\mathrm{C}$} & $50 \mathrm{R}-1,112-114$ & -12.5 & 60.7 & 299.5 & & & & & & \\
\hline & $50 \mathrm{R}-1,134-126$ & -30.5 & 105.7 & 344.5 & 45.8 & 44.7 & -38.1 & 63.5 & 6 & 51.4 \\
\hline \multirow[t]{2}{*}{ D } & $53 \mathrm{R}-3,110-112$ & -13.7 & 115.8 & 354.3 & & & & & & \\
\hline & $53 \mathrm{R}-3,114-116$ & -16.2 & 138.0 & 16.5 & 70.5 & 328.6 & 5.4 & 24.9 & 27 & 28.5 \\
\hline \multirow[t]{3}{*}{$\mathrm{E}$} & $55 \mathrm{R}-2,31-33$ & -29.3 & 196.6 & 14.6 & & & & & & \\
\hline & $55 \mathrm{R}-2,38-40$ & -44.0 & 226.8 & 44.8 & & & & & & \\
\hline & $55 \mathrm{R}-2,46-48$ & -27.8 & 215.8 & 33.8 & 47.2 & 299.3 & 30.8 & 12.1 & 27 & 24.4 \\
\hline \multirow[t]{3}{*}{$\mathrm{F}$} & $57 \mathrm{R}-1,37-39$ & -33.2 & 336.8 & 326.3 & & & & & & \\
\hline & $57 \mathrm{R}-1,42-44$ & -34.9 & 338.2 & 327.7 & & & & & & \\
\hline & $57 \mathrm{R}-1,72-74$ & -34.9 & 355.5 & 345.0 & 49.9 & 26.5 & -26.9 & 7.6 & 67 & 23.2 \\
\hline \multirow[t]{2}{*}{ G } & $57 \mathrm{R}-2,127-129$ & -30.9 & 281.4 & 341.7 & & & & & & \\
\hline & $57 \mathrm{R}-2,134-136$ & -22.8 & 297.7 & 358.0 & 62.7 & 6.4 & -10.1 & 18.3 & 49 & 26.0 \\
\hline \multirow[t]{2}{*}{$\mathrm{H}$} & $59 \mathrm{R}-1,32-34$ & -36.8 & 235.1 & 359.2 & & & & & & \\
\hline & $59 \mathrm{R}-1,38-40$ & -25.2 & 227.6 & 351.7 & 61.7 & 354.1 & -4.6 & 11.2 & 127 & 23.9 \\
\hline
\end{tabular}

Notes: Incl., Decl. = paleomagnetic inclination and declination in sample coordinates; Decl. corr. = paleomagnetic declination corrected to geographic coordinates; Paleopole = average paleomagnetic pole from oriented samples for given feature; Ave. decl. = average declination (relative to Site 869) inferred from paleopole (in degrees); $\alpha_{63}=$ standard deviation of mean pole (in degrees), from Fisher statistics; $k=$ precision parameter of mean pole, also from Fisher statistics; $S_{d}=$ standard deviation of average declination (in degrees) used for mean pole calculation.

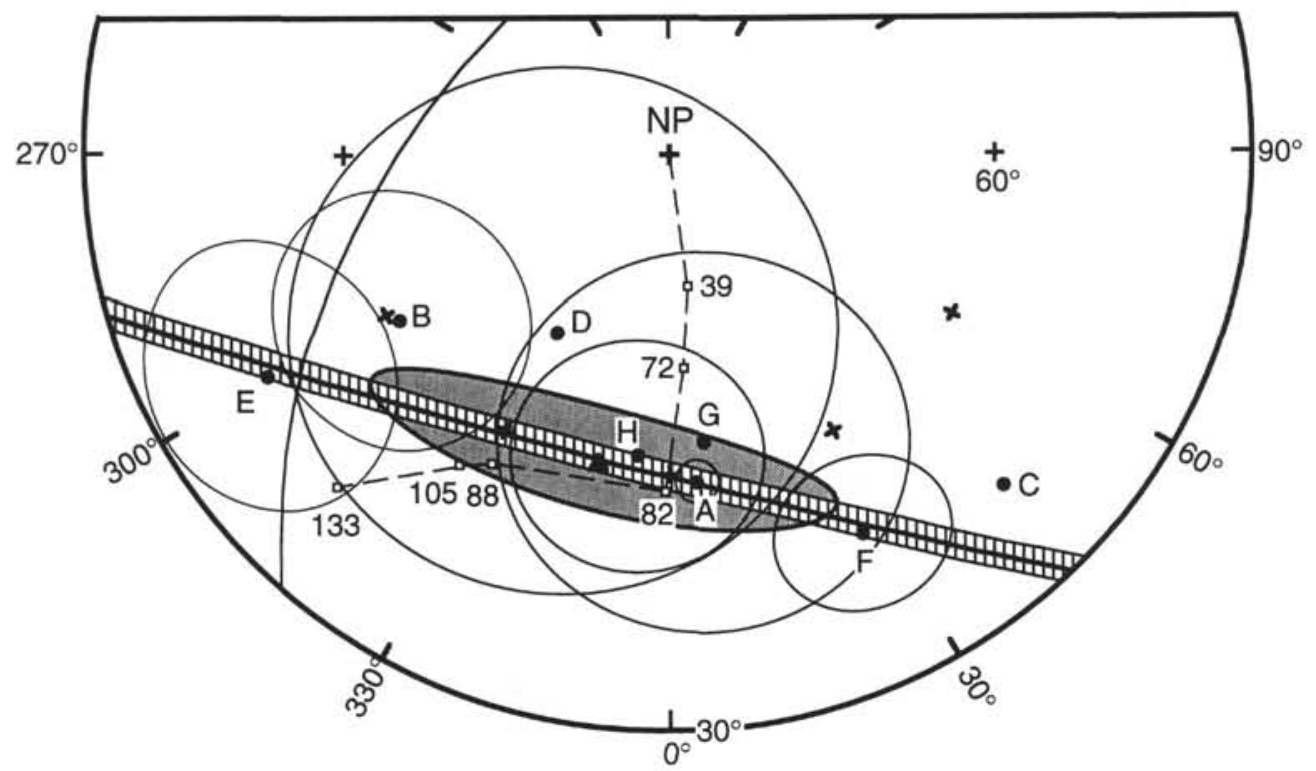

Figure 8. Azimuthally oriented data and mean paleomagnetic pole. Virtual geomagnetic poles calculated from oriented core segments are shown as solid circles, labeled A to G, which correspond to features in Tables 2 and 3. Each mean is surrounded by an $\alpha_{63}$ circle (circular standard deviation); that for feature $\mathrm{C}$ is so large that only a portion appears at left. The mean pole, calculated using a maximum likelihood method (Gordon and Cox, 1980), is shown by the solid triangle and is surrounded by its $95 \%$ confidence ellipse (stippled). The Pacific apparent polar wander path is shown by small, open squares that are connected by a dashed line (see Fig. 6). Polar equal area projection.

\section{ACKNOWLEDGMENTS}

The authors (W.S. and J.T.) thank the JOI/USSAC science support program for providing funds for this study. We also thank $Z$ \& $S$ Consultants, Ltd., for providing proprietary log interpretation software to the Borehole Research Group at the University of Leicester. Craig Jones, of CIRES, at the University of Colorado, Boulder, kindly provided a Macintosh program to plot and analyze sample magnetizations; his many hours of programming and debugging are greatly appreciated. This is Texas A\&M Geodynamics Research Institute Contribution No. 097.

\section{REFERENCES}

Anson, G.L., and Kodama, K.P., 1987. Compaction-induced shallowing of the post-depositional remanent magnetization in a synthetic sediment. Geophys. J. R. Astron. Soc., 88:673-692.

Blow, R.A., and Hamilton, N., 1978. Effect of compaction on the acquisition of a detrital remanent magnetization in fine-grained sediments. Geophys. J. R. Astron. Soc., 52:13-23.

Abbreviations for names of organizations and publications in ODP reference lists follow the style given in Chemical Abstracts Service Source Index (published by American Chemical Society). 
Briden, J.C., and Ward, M.A., 1966. Analysis of magnetic inclination in borecores. Pure Appl. Geophys., 57:47-52.

Cande, S.C., and Kent, D.V., 1992. A new geomagnetic polarity time scale for the Late Cretaceous and Cenozoic. J. Geophys. Res., 97:13917-13951.

Cox, A., and Gordon, R.G., 1984. Paleolatitudes determined from paleomagnetic data from vertical cores. Rev. Geophys. Space Phys., 22:47-72.

Demarest, H.H., Jr., 1983. Error analysis for the determination of tectonic rotation from paleomagnetic data. J. Geophys. Res., 88:4321-4328.

Fisher, R.A., 1953. Dispersion on a sphere, Proc. R. Soc. London A, 217:295305 .

Francheteau, J., Harrison, C.G.A., Sclater, J.G., and Richards, M.L., 1970. Magnetization of Pacific seamounts: a preliminary polar wander curve for the northeastern Pacific. J. Geophys. Res., 75:2035-2061.

Gee, J., Staudigel, H., and Tauxe, L., 1989. Contribution of induced magnetization to magnetization of seamounts. Nature, 342:170-173.

Gee, J., Staudigel, H., Tauxe, L., and Pick, T., 1993. Magnetization of the La Palma Seamount Series: implications for seamount paleopoles. J. Geophys. Res., 98:11743-11767.

Gordon, R.G., 1983. Late Cretaceous apparent polar wander of the Pacific plate: evidence for a rapid shift of the Pacific hotspots with respect to the spin axis. Geophys. Res. Lett. 10:709-712.

1990. Test for bias in paleomagnetically determined paleolatitudes from Pacific plate Deep Sea Drilling Project sediments. J. Geophys. Res. 95:8397-8404.

Gordon, R.G., and Cox, A., 1980. Calculating paleomagnetic poles for oceanic plates. Geophys. J. R. Astron. Soc., 63:619-640.

Harland, W.B., Armstrong, R.L., Cox, A.V., Craig, L.E., Smith, A.G., and Smith, D.G., 1990. A Geologic Time Scale 1989: Cambridge (Cambridge Univ. Press)

Hildebrand, J.A., and Staudigel, H., 1986. Seamount magnetic polarity and Cretaceous volcanism of the Pacific basin. Geology, 14:456-458.

King, R.F., 1955. Remanent magnetism of artificially deposited sediments. Mon. Notes R. Astron. Soc., Geophys. Suppl., 7:117-134.

Kirschvink, J.L., 1980. The least-squares line and plane and analysis of palaeomagnetic data. Geophys. J. R. Astron. Soc., 62:699-718.

Lancelot, Y., and Larson, R.L., 1975. Sedimentary and tectonic evolution of the northwestern Pacific. In Larson, R.L., Moberly, R., et al., Init. Repts. DSDP, 32: Washington (U.S. Govt. Printing Office), 925-939.

Larson, R.L., 1991. Latest pulse of Earth: evidence for a mid-Cretaceous superplume. Geology, 19:547-550.

Larson, R.L., and Lowrie, W., 1975. Paleomagnetic evidence for motion of the Pacific plate from Leg 32 basalts and magnetic anomalies. In Larson, R.L., and Moberly, R., et al., Init. Repts. DSDP, 32: Washington (U.S. Govt. Printing Office), 571-577.

Larson, R.L., Steiner, M.B., Erba, E., and Lancelot, Y., 1992. Paleolatitudes and tectonic reconstructions of the oldest portion of the Pacific Plate: a comparative study. In Larson, R.L., Lancelot, Y., et al., Proc. ODP, Sci. Results, 129: College Station, TX (Ocean Drilling Program), 615-631.

MacLeod, C.J., Parson, L.M., and Sager, W.W., 1994. Reorientation of cores using the Formation MicroScanner and Borehole Televiewer: application to structural and paleomagnetic studies with the Ocean Drilling Program. In Hawkins, J., Parson, L., Allan, J., et al., Proc. ODP, Sci. Results, 135: College Station, TX (Ocean Drilling Program), 301-311.

MacLeod, C.J., Parson, L.M., Sager, W.W., and the ODP Leg 135 Scientific Party, 1992. Identification of tectonic rotations in boreholes by the integration of core information with Formation MicroScanner and Borehole Televiewer images. In Hurst, A., Griffiths, C.M., and Worthington, P.F.
(Eds.), Geological Applications of Wireline Logs II. Geol. Soc. Spec. Publ. London, 65:235-246.

McElhinny, M.W., 1973. Palaeomagnetism and Plate Tectonics: Cambridge (Cambridge Univ. Press).

McFadden, P.L., and Reid, A.B., 1982. Analysis of paleomagnetic inclination data. Geophys. J. R. Astron. Soc., 69:307-319.

Nakanishi, M., Tamaki, K., and Kobayashi, K., 1992. A new Mesozoic isochron chart of the northwestern Pacific Ocean: paleomagnetic and tectonic implications. Geophys. Res. Lett., 19:693-696.

Premoli Silva, I., Haggerty, J., Rack, F., et al., 1993. Proc. ODP, Init. Repts., 144: College Station, TX (Ocean Drilling Program).

Sager, W.W., 1992. Seamount age estimates from paleomagnetism and their implications for the history of volcanism on the Pacific Plate. In Keating, B.H., and Bolton, B.R. (Eds.), Geology and Offshore Mineral Resources of the Central Pacific Basin. Circum-Pac. Counc. Energy Miner. Resour., Earth Sci. Ser., 14:21-37.

Sager, W.W., MacLeod, C.J., and Abrahamsen, N., 1994. Paleomagnetic constraints on Tonga Arc tectonic rotation from sediments drilled at Sites 840 and 841. In Hawkins, J., Parson, L., Allan, J., et al., Proc. ODP, Sci. Results, 135: College Station, TX (Ocean Drilling Program), 763-783.

Sager, W.W., and Pringle, M.S., 1988. Mid-Cretaceous to Early Tertiary apparent polar wander path of the Pacific Plate. J. Geophys. Res., 93:11753-11771.

Sager, W.W., Winterer, E.L., Firth, J.V., et al., 1993. Proc. ODP, Init. Repts., 143: College Station, TX (Ocean Drilling Program).

Schlanger, S.O., Jenkyns, H.C., and Premoli Silva, I., 1981. Volcanism and vertical tectonics in the Pacific basin related to global Cretaceous transgressions. Earth Planet. Sci. Lett., 52:435-449.

Shibuya, H., Merrill, D.L., Hsu, V., and Leg 124 Shipboard Scientific Party, 1991. Paleogene counterclockwise rotation of the Celebes Sea - orientation of ODP cores utilizing the secondary magnetization. In Silver, E.A., Rangin, C., von Breymann, M.T., et al., Proc. ODP, Sci. Results, 124: College Station, TX (Ocean Drilling Program), 519-523.

Steiner, M. B., 1983. Geomagnetic excursion in the Late Cretaceous. Geophys. J. R. Astr. Soc., 73:17-25.

Steiner, M.B., and Wallick, B.P., 1992. Jurassic to Paleocene paleolatitudes of the Pacific Plate derived from the paleomagnetism of the sedimentary sequences at Sites 800, 801, and 802. In Larson, R.L., Lancelot, Y., et al., Proc. ODP, Sci. Results, 129: College Station, TX (Ocean Drilling Program), 431-446.

Tarduno, J.A., 1990. Absolute inclination values from deep sea sediments: a reexamination of the Cretaceous Pacific record. Geophys. Res. Lett., 17:101-104.

Tarduno, J.A., Lowrie, W., Sliter, W.V., Bralower, T.J., and Heller, F., 1992. Reversed polarity characteristic magnetizations in the Albian Contessa section, Umbrian Apennines, Italy: implications for the existence of a mid-Cretaceous mixed polarity interval. J. Geophys. Res., 97:241-271.

Tarduno, J.A., Sliter, W.V., Kroenke, L., Leckie, M., Mayer, H., Mahoney, J.J., Musgrave, R., Storey, M., and Winterer, E.L., 1991. Rapid formation of Ontong-Java Plateau by Aptian mantle plume volcanism. Science, 254:399-403.

Date of initial receipt: 29 November 1993

Date of acceptance: 9 May 1994

Ms 143SR-233 
APPENDIX

Sample Paleomagnetic and Lithological Data, Hole 869B

\begin{tabular}{|c|c|c|c|c|c|c|c|c|c|c|}
\hline $\begin{array}{l}\text { Core, section, } \\
\text { interval }(\mathrm{cm})\end{array}$ & $\begin{array}{l}\text { Depth } \\
\text { (mbsf) }\end{array}$ & $\begin{array}{c}\text { Decl. } \\
\text { (degrees) }\end{array}$ & $\begin{array}{c}\text { Incl. } \\
\text { (degrees) }\end{array}$ & $N$ & MAD & Steps & $\begin{array}{c}J_{o} \\
(\mathrm{~mA} / \mathrm{m})\end{array}$ & $J_{n} / J_{o}$ & $\begin{array}{l}\text { Susc. } \\
\left(\times 10^{-5}\right)\end{array}$ & Sed. Type \\
\hline $11 \mathrm{R}-3,147$ & 231.47 & 183 & -28.8 & 7 & 7.7 & $17-45$ & 70.307 & 0.157 & 1828.1 & Sandstone \\
\hline $11 \mathrm{R}-4,4$ & 231.44 & 359.7 & -13.6 & 8 & 2.6 & $20-60$ & 261.132 & 0.042 & 1523.5 & Sandstone \\
\hline $11 R-4,139$ & 232.79 & 344.7 & -37 & 8 & 1.6 & $250-600$ & 718.476 & 0.083 & 1289.3 & Claystone \\
\hline $13 \mathrm{R}-1,3$ & 246.23 & 302.7 & -6.2 & 6 & 0.9 & $350-600$ & 239.651 & 0.118 & 368.8 & Claystone \\
\hline $13 \mathrm{R}-2,61$ & 248.31 & 298.1 & -26.7 & 5 & 4.2 & $25-45$ & 153.09 & 0.072 & 675.3 & Sandstone \\
\hline $13 R-4,67$ & 251.37 & 50 & -15.8 & 9 & 1.8 & $150-600$ & 111.1 & 0.137 & 837.9 & Claystone \\
\hline $15 \mathrm{R}-2,148$ & 268.38 & 270.2 & -21.3 & 10 & 4.3 & $150-550$ & 198.742 & 0.064 & 1953.8 & Sandstone \\
\hline $15 \mathrm{R}-3,122$ & 269.62 & 93 & -6.6 & 8 & 2.1 & $15-50$ & 119.141 & 0.210 & 493 & Claystone \\
\hline $15 R-4,3$ & 269.93 & 223 & -20.81 & 5 & 2.1 & $200-400$ & 249.445 & 0.514 & 327.1 & Claystone \\
\hline $15 R-4,95$ & 270.85 & 167 & -21.1 & 5 & 3 & $200-400$ & 142.409 & 0.606 & 286.4 & Claystone \\
\hline $16 \mathrm{R}-1,41$ & 275.51 & 171 & -22 & 6 & 0.8 & $15-60$ & 107.591 & 0.168 & 208.7 & Claystone \\
\hline $17 \mathrm{R}-2,44$ & 286.74 & 175.8 & -18.1 & 7 & 3.8 & $300-600$ & 94.532 & 0.127 & 2516.9 & Sandstone \\
\hline $19 \mathrm{R}-1,22$ & 304.32 & 135.8 & -37.7 & 7 & 4.5 & $250-550$ & 202.093 & 0.057 & 2390.6 & Sandstone \\
\hline $19 \mathrm{R}-1,31$ & 304.41 & 347.1 & -23.21 & 6 & 1.9 & $150-400$ & 528.119 & 0.117 & 2131 & Sandstone \\
\hline $19 \mathrm{R}-1,106$ & 305.16 & 153.2 & 24.8 & 3 & 6.4 & $450-550$ & 172.103 & 0.052 & 2108.7 & Sandstone \\
\hline $19 \mathrm{R}-3,65$ & 308.05 & 129 & -33.9 & 7 & 1.8 & $100-500$ & 271.779 & 0.135 & 2705 & Sandstone \\
\hline $20 \mathrm{R}-1,64$ & 314.44 & 315.8 & -10.8 & 5 & 2.4 & $200-400$ & 300.521 & 0.352 & 399.4 & Claystone \\
\hline $20 \mathrm{R}-1,68$ & 314.48 & 313 & -13.4 & 4 & 5.7 & $50-80$ & 614.716 & 0.046 & & \\
\hline $20 \mathrm{R}-1,123$ & 315.03 & 65 & -29.5 & 5 & 9.3 & $200-400$ & 185.556 & 1.924 & 451.6 & Claystone \\
\hline $20 \mathrm{R}-1,131$ & 315.11 & 10.1 & -21.2 & 6 & 1.1 & $20-60$ & 479.769 & 0.095 & 829.5 & Claystone \\
\hline $20 \mathrm{R}-2,37$ & 315.67 & 247.7 & 3.1 & 5 & 4.2 & $300-550$ & 124.053 & 0.169 & 1049.4 & Sandstone \\
\hline $20 \mathrm{R}-3,25$ & 317.5 & 16.2 & -22.1 & 13 & 3.6 & $100-600$ & 344.289 & 0.056 & 740.2 & Claystone \\
\hline $20 \mathrm{R}-3,116$ & 317.96 & 275.4 & -34.2 & 2 & 3.2 & $50-60$ & 786.911 & 0.065 & & \\
\hline 20R-CC, 3 & 318.89 & 295.2 & 9.5 & 7 & 2.5 & $250-550$ & 335.34 & 0.024 & 1567.5 & Sandstone \\
\hline $21 \mathrm{R}-1,14$ & 323.64 & NS & & & & & 386.611 & & & \\
\hline $22 \mathrm{R}-1,70$ & 333.8 & NS & & & & & 59.921 & & & \\
\hline $22 \mathrm{R}-1,115$ & 334.25 & 323.4 & -20 & 5 & 3.7 & $100-300$ & 203.246 & 0.168 & 1344.1 & Siltstone \\
\hline $22 \mathrm{R}-1,134$ & 334.44 & 84.2 & 19.1 & 4 & 6.7 & $50-80$ & 713.898 & 0.067 & & \\
\hline $22 \mathrm{R}-2,6$ & 334.66 & 54 & 24.4 & 4 & 7.9 & $50-80$ & 352.719 & 0.048 & & \\
\hline $22 \mathrm{R}-2,64$ & 335.24 & 180.5 & 41.2 & 5 & 2.9 & $350-550$ & 76.845 & 0.143 & 422.2 & Siltstone \\
\hline $22 \mathrm{R}-2,86$ & 335.46 & NS & & & & & 208.123 & & 1301.4 & Sandstone \\
\hline $22 \mathrm{R}-3,10$ & 336.2 & 232.6 & -44 & 3 & 8 & $50-70$ & 156.911 & 0.255 & & \\
\hline $23 \mathrm{R}-1,60$ & 343.4 & NS & & & & & 75.562 & & & \\
\hline $23 \mathrm{R}-2,51$ & 344.81 & 115.7 & 29.9 & 3 & 6.3 & $300-400$ & 70.195 & 0.557 & 589.2 & Claystone \\
\hline $23 \mathrm{R}-2,65$ & 344.95 & 43.9 & -25.8 & 6 & 2.9 & $100-250$ & 170.108 & 0.424 & 485.5 & Claystone \\
\hline $23 \mathrm{R}-2,113$ & 345.43 & 352.6 & -54.1 & 4 & 4.1 & $250-400$ & 139.702 & 0.207 & 847.8 & Sandstone \\
\hline $25 \mathrm{R}-1,120$ & 363.4 & 187.6 & 9.4 & 4 & 3.4 & $250-400$ & 14.816 & 0.113 & 198.9 & Claystone \\
\hline $25 \mathrm{R}-2,1$ & 363.71 & 49.4 & 45.2 & 4 & 2.2 & $7-30$ & 53.235 & 0.132 & 358.8 & Sandstone \\
\hline $25 \mathrm{R}-2,130$ & 365 & NS & & & & & 134.005 & & 242 & Sandstone \\
\hline $25 \mathrm{R}-3,24$ & 365.44 & 259.9 & 23.8 & 6 & 2.6 & $300-550$ & 14.821 & 0.200 & 106.9 & Siltstone \\
\hline $25 \mathrm{R}-3,77$ & 365.97 & 69.4 & 12.4 & 8 & 2.2 & $200-600$ & 77.59 & 0.132 & 523.4 & Claystone \\
\hline $26 \mathrm{R}-1,30$ & 372.1 & 122.6 & 10.2 & 5 & 5.1 & $300-500$ & 18.145 & 0.111 & 135.2 & Siltstone \\
\hline $26 \mathrm{R}-1,54$ & 372.34 & 328.1 & 11 & 6 & 0.9 & $15-60$ & 257.099 & 0.086 & & \\
\hline $26 \mathrm{R}-1,145$ & 373.25 & 187.1 & 48.3 & 5 & 5.7 & $200-400$ & 6.478 & 0.286 & 51.2 & Siltstone \\
\hline $27 \mathrm{R}-1,62$ & 382.12 & 284.4 & -30.1 & 5 & 5.1 & $25-50$ & 15.543 & 0.299 & 178 & Claystone \\
\hline $30 \mathrm{R}-1,24$ & 410.64 & 186.7 & -25.7 & 7 & 2 & $20-70$ & 16.496 & 0.072 & 46.2 & Claystone \\
\hline $31 \mathrm{R}-1,89$ & 411.99 & 210.2 & -18.7 & 11 & 1 & $150-600$ & 76.469 & 0.492 & 178.7 & Claystone \\
\hline $31 \mathrm{R}-1,119$ & 412.29 & 349.2 & -18 & 9 & 2 & $150-600$ & 203.284 & 0.230 & 168.2 & Claystone \\
\hline $32 \mathrm{R}-1,14$ & 429.94 & 481 & -20.6 & 6 & 1.3 & $15-60$ & 547.99 & 0.088 & & Claystone \\
\hline $32 \mathrm{R}-2,16$ & 431.46 & 328.2 & -29.2 & 8 & 2.6 & $200-550$ & 259.078 & 0.227 & 873.8 & Claystone \\
\hline $32 \mathrm{R}-3,12$ & 432.92 & 189.7 & -19.2 & 7 & 2 & $250-600$ & 566.332 & 0.272 & 337.5 & Claystone \\
\hline $33 \mathrm{R}-1,44$ & 439.84 & 82.4 & -18.9 & 8 & 2.6 & $250-600$ & 396.32 & 0.201 & 468.6 & Claystone \\
\hline $33 \mathrm{R}-1,88$ & 440.26 & 151.3 & -29.9 & 7 & 1.1 & $15-80$ & 1023.822 & 0.069 & & \\
\hline $34 \mathrm{R}-1,136$ & 450.46 & 344.5 & -22.2 & 9 & 1.1 & $15-70$ & 77.355 & 0.101 & 141.6 & Siltstone \\
\hline $34 \mathrm{R}-2,18$ & 450.78 & 83 & -29.2 & 5 & 1.6 & $200-400$ & 98.712 & 0.469 & 78 & Siltstone \\
\hline $34 \mathrm{R}-2,71$ & 451.31 & 269.9 & -12.7 & 6 & 2.8 & $150-400$ & 711.934 & 0.056 & 501.3 & Siltstone \\
\hline $34 \mathrm{R}-2,83$ & 451.43 & 36.9 & -40.7 & 6 & 3.4 & $150-400$ & 625.344 & 0.480 & 767 & Claystone \\
\hline $34 R-2,96$ & 451.56 & 211.4 & -33.8 & 7 & 1.5 & $15-80$ & 572.966 & 0.086 & & \\
\hline $34 \mathrm{R}-2,125$ & 451.85 & 204.4 & -24.6 & 9 & 1.8 & $200-600$ & 148.579 & 0.323 & 647.5 & Claystone \\
\hline $34 \mathrm{R}-3,35$ & 452.45 & 177.9 & -11.7 & 7 & 1.7 & $15-80$ & 431.412 & 0.091 & & \\
\hline $35 \mathrm{R}-1,54$ & 459.34 & 355.7 & -19.9 & 7 & 2.6 & $200-500$ & 88.422 & 0.102 & 212.5 & Claystone \\
\hline $35 \mathrm{R}-1,84$ & 459.64 & 240.9 & -24.9 & 6 & 1.3 & $10-50$ & 233.485 & 0.125 & & \\
\hline $36 \mathrm{R}-1,104$ & 469.44 & 292.8 & -17.4 & 5 & 0.6 & $400-600$ & 527.839 & 0.176 & 670.3 & Siltstone \\
\hline $36 \mathrm{R}-2,130$ & 471.2 & 173 & -21.4 & 7 & 0.7 & $10-60$ & 875.171 & 0.117 & & \\
\hline $36 \mathrm{R}-3,49$ & 471.89 & 356 & -26.2 & 8 & 0.8 & $200-600$ & & 0.173 & 398.9 & Claystone \\
\hline $36 \mathrm{R}-4,27$ & 473.17 & 12.6 & -21.5 & 8 & 1.5 & $20-55$ & 363.824 & 0.071 & 376.1 & Claystone \\
\hline $36 \mathrm{R}-4,50$ & 473.4 & 267.7 & -25.2 & 6 & 2.3 & $350-600$ & 250.983 & 0.390 & 590.6 & Claystone \\
\hline $38 \mathrm{R}-2,10$ & 489.3 & NS & & & & & 50.262 & & 211.2 & Coarse volc. \\
\hline $38 \mathrm{R}-3,4$ & 490.74 & 291.6 & -21.4 & 4 & 1.6 & $450-600$ & 379.535 & 0.030 & 340.6 & Coarse volc. \\
\hline $39 \mathrm{R}-1,99$ & 498.39 & NS & & & & & 81.164 & & 537.6 & Sandstone \\
\hline $39 \mathrm{R}-1,123$ & 498.63 & 223.2 & 10.2 & 5 & 2.9 & $400-600$ & 60.051 & 0.200 & 220.2 & Coarse volc. \\
\hline $40 \mathrm{R}-2,69$ & 509.29 & 62.4 & -44.8 & 7 & 5 & $15-50$ & 70.135 & 0.197 & 199.3 & Sandstone \\
\hline $40 \mathrm{R}-2,111$ & 509.71 & 178.3 & -32.7 & 5 & 4.8 & $300-500$ & 43.717 & 0.205 & 215.1 & Sandstone \\
\hline $41 \mathrm{R}-2,75$ & 519.05 & 342.7 & -3 & 6 & 5.1 & $250-500$ & 50.153 & 0.262 & 222.9 & Coarse volc. \\
\hline $41 \mathrm{R}-2,88$ & 519.18 & 1.7 & -55 & 6 & 3.2 & $25-80$ & 59.998 & 0.136 & 234.3 & Coarse volc. \\
\hline $42 R-4,60$ & 531.5 & NS & & & & & 3701.673 & & 443 & Coarse volc. \\
\hline $43 \mathrm{R}-1,10$ & 536.2 & 220.6 & -31.3 & 7 & 3.3 & $25-80$ & 384.222 & 0.089 & 196.3 & Coarse volc. \\
\hline $43 R-2,106$ & 538.66 & 95.6 & -31.1 & 5 & 1 & $200-400$ & 148.905 & 0.242 & 459.4 & Sandstone \\
\hline $44 \mathrm{R}-3,36$ & 548.96 & 195.9 & -23.4 & 5 & 6.3 & $350-600$ & 80.514 & 0.099 & 397 & Sandstone \\
\hline $44 R-5,16$ & 551.76 & 22.11 & -38.4 & 8 & 3.3 & $250-600$ & 136.665 & 0.029 & 413.6 & Sandstone \\
\hline $45 \mathrm{R}-3,64$ & 558.94 & 314.31 & -30.6 & 5 & 1.6 & $150-350$ & 265.167 & 0.094 & 498.2 & Coarse volc. \\
\hline $45 \mathrm{R}-3,76$ & 559.06 & 308 & -31.8 & 8 & 3 & $250-600$ & 112.753 & 0.032 & 493.7 & Sandstone \\
\hline $45 \mathrm{R}-3,105$ & 559.36 & 307.2 & -34 & 8 & 2 & $250-600$ & 83.051 & 0.022 & 403.1 & Sandstone \\
\hline $45 \mathrm{R}-3,110$ & 559.41 & 309.1 & -36 & 6 & 6.9 & $250-600$ & 87.819 & 0.144 & 431.4 & Sandstone \\
\hline $45 \mathrm{R}-4,11$ & 559.91 & 325.6 & -34.9 & 6 & 3.6 & $250-600$ & 95.023 & 0.044 & 444.4 & Sandstone \\
\hline $45 R-4,22$ & 559.48 & 346.5 & -6.4 & 3 & 2.1 & $150-250$ & 159.216 & 0.453 & 412.9 & Sandstone \\
\hline $45 R-4,27$ & 559.53 & 351.1 & -18 & 4 & 3.2 & $150-300$ & 163.141 & 0.282 & 399 & Sandstone \\
\hline
\end{tabular}


APPENDIX (continued).

\begin{tabular}{|c|c|c|c|c|c|c|c|c|c|c|}
\hline $\begin{array}{l}\text { Core, section, } \\
\text { interval }(\mathrm{cm})\end{array}$ & $\begin{array}{l}\text { Depth } \\
\text { (mbsf) }\end{array}$ & $\begin{array}{c}\text { Decl. } \\
\text { (degrees) }\end{array}$ & $\begin{array}{c}\text { Incl. } \\
\text { (degrees) }\end{array}$ & $N$ & MAD & Steps & $\underset{(\mathrm{mA} / \mathrm{m})}{J_{0}}$ & $J_{n} / J_{0}$ & $\begin{array}{l}\text { Susc. } \\
\left(\times 10^{-5}\right)\end{array}$ & Sed. Type \\
\hline $45 R-4,41$ & 560.21 & NS & & & & & 43.733 & & 442.9 & Sandstone \\
\hline $45 \mathrm{R}-4,53$ & 560.33 & 151.2 & -35.1 & 6 & 2.3 & $200-450$ & 78.134 & 0.023 & 430.3 & Sandstone \\
\hline $46 \mathrm{R}-1,4$ & 564.64 & 192.7 & -40.2 & 6 & 2.1 & $250-500$ & 84.519 & 0.188 & 414.6 & Sandstone \\
\hline $48 \mathrm{R}-1,46$ & 584.36 & 167.2 & 41.7 & 5 & 9.6 & $400-600$ & 110.321 & 0.022 & 274.4 & Sandstone \\
\hline $50 \mathrm{R}-1,112$ & 604.32 & 60.7 & -12.5 & 5 & 4 & $250-400$ & 176.269 & 0.125 & 498 & Sandstone \\
\hline $50 \mathrm{R}-1,124$ & 604.44 & 105.7 & -30.5 & 5 & 2.3 & $300-500$ & 98.19 & 0.082 & 584.9 & Sandstone \\
\hline $50 \mathrm{R}-3,45$ & 606.65 & 136.6 & -25 & 6 & 6.3 & $200-500$ & 112.039 & 0.214 & 668.8 & Sandstone \\
\hline $51 R-2,13$ & 614.33 & 158.4 & -24.8 & 6 & 3 & $30-80$ & 329.78 & 0.039 & 380.2 & Siltstone \\
\hline $51 \mathrm{R}-2,35$ & 614.55 & 353.1 & -44.7 & 6 & 1.4 & $250-500$ & 143.96 & 0.063 & 434.3 & Sandstone \\
\hline $51 \mathrm{R}-2,118$ & 615.38 & 90.3 & -30.5 & 4 & 3.5 & $250-400$ & 258.362 & 0.337 & 535.6 & Siltstone \\
\hline $51 \mathrm{R}-2,122$ & 615.42 & 75 & -42.3 & 4 & 3.2 & $250-400$ & 288.71 & 0.363 & 679.1 & Siltstone \\
\hline $51 \mathrm{R}-3,84$ & 616.54 & 113.5 & -72.2 & 4 & 2 & $200-350$ & 55.808 & 0.407 & 304.9 & Sandstone \\
\hline $51 \mathrm{R}-3,89$ & 616.59 & 255.8 & -64.4 & 5 & 4.8 & $150-350$ & 44.266 & 0.659 & 393 & Sandstone \\
\hline $52 \mathrm{R}-2,54$ & 624.44 & 253.8 & 2.1 & 6 & 1.4 & $350-600$ & 315.936 & 0.072 & 575.1 & Claystone \\
\hline $52 \mathrm{R}-2,64$ & 624.54 & 214.1 & 44.3 & 7 & 3 & $300-600$ & 236.353 & 0.102 & 619.3 & Claystone \\
\hline $52 \mathrm{R}-2,74$ & 624.64 & 240.8 & 6.3 & 4 & 1.8 & $30-80$ & 250.039 & 0.028 & 723.6 & Claystone \\
\hline $52 \mathrm{R}-2,99$ & 624.89 & 263.3 & 21.1 & 6 & 1.4 & $350-600$ & 368.01 & 0.054 & 732.6 & Claystone \\
\hline $52 \mathrm{R}-2,123$ & 625.13 & 250.4 & 11.2 & 7 & 1.9 & $100-450$ & 523.25 & 0.275 & 654.2 & Claystone \\
\hline $52 \mathrm{R}-3,30$ & 625.7 & 275.2 & -25.2 & 9 & 1.6 & $200-600$ & 346.39 & 0.056 & 666.5 & Siltstone \\
\hline $52 \mathrm{R}-3,64$ & 626.04 & 272 & -30.3 & 6 & 2.6 & $200-450$ & 206.893 & 0.232 & 537.2 & Siltstone \\
\hline $53 \mathrm{R}-1,88$ & 632.88 & NS & . & & 2.0 & 2000.50 & 82.889 & & 305.8 & Coarse volc. \\
\hline $53 R-2,4$ & 633.54 & 355.6 & -11 & 4 & 6.2 & $400-550$ & 71.234 & 0.056 & 287.6 & Coarse volc. \\
\hline $53 \mathrm{R}-2,30$ & 633.9 & NS & & & & & 16.382 & & 270.3 & Coarse volc. \\
\hline $53 \mathrm{R}-3,110$ & 636 & 115.8 & -13.7 & 6 & 3 & $150-400$ & 139.596 & 0.307 & 265.8 & Sandstone \\
\hline $53 R-3,114$ & 636.04 & 318 & 16.2 & 4 & 7.3 & $400-550$ & 73.857 & 0.095 & 276.7 & Coarse volc. \\
\hline $55 \mathrm{R}-2,28$ & 653.28 & 23.9 & -20.2 & 5 & 2.5 & $200-400$ & 216.901 & 0.230 & 436.8 & Siltstone \\
\hline $55 \mathrm{R}-2,38$ & 653.38 & 226.8 & -44 & 4 & 4.7 & $400-550$ & 81.329 & 0.074 & 516.5 & Sandstone \\
\hline $55 \mathrm{R}-2,31$ & 653.31 & 196.6 & -29.3 & 8 & 2.4 & $150-500$ & 100.443 & 0.132 & 515 & Claystone \\
\hline $55 \mathrm{R}-2,46$ & 653.46 & 215.8 & -27.8 & 8 & 3.4 & $15-60$ & 108.759 & 0.088 & 633.6 & Claystone \\
\hline $56 \mathrm{R}-1,84$ & 662.04 & 91.2 & -59.6 & 4 & 2.4 & $450-600$ & 629.37 & 0.030 & 707.4 & Sandstone \\
\hline $56 \mathrm{R}-2,32$ & 663.02 & NS & & & & & 22.188 & & 272.6 & Sandstone \\
\hline $57 \mathrm{R}-1,16$ & 670.86 & 344.6 & -36.6 & 6 & 1.3 & $150-400$ & 144.865 & 0.145 & 271.7 & Siltstone \\
\hline $57 \mathrm{R}-1,28$ & 670.98 & 358.2 & -19.8 & 6 & 2.4 & $150-400$ & 118.366 & 0.195 & 251 & Siltstone \\
\hline $57 \mathrm{R}-1,37$ & 671.07 & 336.8 & -33.2 & 6 & 2.1 & $150-400$ & 134.782 & 0.163 & 228.7 & Siltstone \\
\hline $57 \mathrm{R}-1,42$ & 671.12 & 338.2 & -34.9 & 5 & 5 & $350-550$ & 102.173 & 0.059 & 228.5 & Siltstone \\
\hline $57 \mathrm{R}-1,72$ & 671.42 & 355.5 & -34.9 & 6 & 1.7 & $200-500$ & 94.002 & 0.106 & 247 & Claystone \\
\hline 57R-2, 127 & 673.47 & 281.4 & -30.9 & 5 & 1.2 & $350-550$ & 175.109 & 0.171 & 272.5 & Siltstone \\
\hline $57 \mathrm{R}-2,134$ & 673.54 & 297.7 & -22.8 & 6 & 2 & $150-400$ & 221.541 & 0.374 & 311.4 & Claystone \\
\hline $57 \mathrm{R}-3,37$ & 674.07 & 214.7 & -32.5 & 6 & 1.3 & $300-550$ & 64.265 & 0.141 & 252 & Siltstone \\
\hline $58 \mathrm{R}-1,134$ & 681.74 & NS & & & & & 257.842 & & 183.3 & Coarse volc. \\
\hline $58 \mathrm{R}-2,83$ & 682.73 & NS & & & & & 396.11 & & 186.9 & Coarse volc. \\
\hline $59 \mathrm{R}-1,32$ & 690.32 & 235.1 & -36.8 & 5 & 1.6 & $150-300$ & 42.211 & 0.191 & 73.2 & Claystone \\
\hline $59 \mathrm{R}-1,38$ & 690.38 & 227.6 & -25.2 & 7 & 4.5 & $200-500$ & 53.133 & 0.189 & 81.3 & Siltstone \\
\hline $59 \mathrm{R}-1,72$ & 690.72 & 117.6 & -33.4 & 7 & 3.7 & $100-500$ & 27.302 & 0.185 & 97.9 & Sandstone \\
\hline $59 \mathrm{R}-3,59$ & 693.59 & 121.3 & $=44$ & 6 & 3 & $300-550$ & 40.566 & 0.073 & 86.6 & Siltstone \\
\hline $60 \mathrm{R}-8,35$ & 710.55 & $216 .-3$ & -41.8 & 6 & 2.8 & $20-45$ & 92.0191 & 0.207 & 184.1 & Claystone \\
\hline $60 \mathrm{R}-8,39$ & 710.59 & 193.3 & -35.5 & 8 & 1.0 & $250-600$ & 61.602 & 0.272 & 203 & Claystone \\
\hline $61 \mathrm{R}-3,90$ & 713.3 & 335.7 & -34.5 & 7 & 1.7 & $20-80$ & 95.266 & 0.120 & 159.2 & Siltstone \\
\hline $61 \mathrm{R}-3,97$ & 713.37 & 336.3 & -39 & 6 & 3.2 & $300-550$ & 55.858 & 0.065 & 151.3 & Siltstone \\
\hline $63 R-2,41$ & 730.61 & 248.8 & -29.1 & 5 & 2.4 & $400-600$ & 13.006 & 0.091 & 86.1 & Claystone \\
\hline $63 \mathrm{R}-2,55$ & 730.75 & 251.2 & -31 & 5 & 1.1 & $400-600$ & 46.267 & 0.078 & 115.1 & Claystone \\
\hline $63 \mathrm{R}-2,69$ & 730.89 & 260.4 & -27.4 & 6 & 1.7 & $15-60$ & 63.978 & 0.103 & 135.7 & Siltstone \\
\hline $63 R-2,76$ & 730.96 & 14.5 & $\begin{array}{l}-23.7 \\
-23.7\end{array}$ & 4 & 1.4 & $450-600$ & 254.034 & 0.019 & 143.2 & Siltstone \\
\hline $63 \mathrm{R}-2,88$ & 731.08 & 257.1 & -32.5 & 9 & 0.9 & $200-600$ & 49.63 & 0.048 & 147.5 & Siltstone \\
\hline $63 \mathrm{R}-2,98$ & 731.18 & 229 & -28.6 & 5 & 2.4 & $20-50$ & 72.539 & 0.137 & 133.3 & Siltstone \\
\hline $63 \mathrm{R}-2,109$ & 731.29 & 224.8 & $\begin{array}{l}-20.0 \\
-36.2\end{array}$ & 8 & 2.4 & $200-600$ & 45.365 & 0.055 & 126.5 & Siltstone \\
\hline $63 \mathrm{R}-3,41$ & 732.11 & 183.6 & -38.6 & 8 & 2.2 & $15-70$ & 90.554 & 0.046 & 128.1 & Siltstone \\
\hline $64 \mathrm{R}-3,104$ & 742.44 & 160.6 & -35.3 & 4 & 2.5 & $200-350$ & 43.583 & 0.318 & 92.5 & Siltstone \\
\hline $65 \mathrm{R}-3,36$ & 751.26 & 347.4 & -42.8 & 8 & 2.9 & $15-60$ & 36.667 & 0.081 & 82.7 & Siltstone \\
\hline $65 \mathrm{R}-4,40$ & 752.8 & meas lost & & & & & & & & Siltstone \\
\hline $66 \mathrm{R}-2,114$ & 760.24 & 161.6 & -29.1 & 5 & 1.1 & $200-400$ & 23.946 & 0.208 & 71.3 & Siltstone \\
\hline $66 \mathrm{R}-3,45$ & 761.05 & 188.9 & 21.8 & 5 & 3.5 & $400-600$ & 20.707 & 0.095 & 92.4 & Coarse volc. \\
\hline $67 R-3,2$ & 770.32 & 250.7 & -37.8 & 10 & 1.4 & $175-600$ & 43.084 & 0.097 & 98.2 & Claystone \\
\hline $67 R-3,10$ & 770.4 & 252.2 & -33.3 & 8 & 2.6 & $200-600$ & 64.83 & 0.083 & 110.6 & Claystone \\
\hline $67 \mathrm{R}-3,28$ & 770.58 & 228.1 & -34.5 & 6 & 0.9 & $350-600$ & 82.937 & 0.080 & 140.2 & Claystone \\
\hline $67 \mathrm{R}-3,42$ & 770.72 & 260 & -33.9 & 11 & 1.1 & $150-600$ & 97.064 & 0.074 & 147.5 & Claystone \\
\hline $67 \mathrm{R}-3,56$ & 770.86 & 261.4 & -22.5 & 11 & 1.6 & $150-600$ & 105.844 & 0.068 & 164.7 & Claystone \\
\hline $67 \mathrm{R}-3,81$ & 771.11 & $\begin{array}{l}201.4 \\
180.2\end{array}$ & -31.2 & 7 & 0.5 & $300-600$ & 112.376 & $\begin{array}{l}0.0080 \\
0.080\end{array}$ & 141.6 & Claystone \\
\hline 67R-6, 14 & 774.94 & 193.5 & -29.4 & 5 & 1 & $300-550$ & 239.03 & 0.126 & 184.4 & Claystone \\
\hline $67 \mathrm{R}-6,17$ & 774.97 & 195.1 & -34.7 & 6 & 1.8 & $350-$ & 99.858 & 0.084 & 170.7 & Claystone \\
\hline $68 \mathrm{R}-3,124$ & 781.14 & 158.3 & -41.4 & 6 & 2.2 & $20-50$ & 88.367 & 0.109 & 182.5 & Claystone \\
\hline $68 \mathrm{R}-3,148$ & 781.38 & 165.5 & -40 & 7 & 1.6 & $300-600$ & 52.839 & 0.114 & 208.1 & Claystone \\
\hline $68 \mathrm{R}-4,5$ & 781.45 & 279.8 & -22.8 & 6 & $\begin{array}{l}1.0 \\
1.6\end{array}$ & $300-550$ & 53.413 & 0.124 & 174.3 & Claystone \\
\hline $68 \mathrm{R}-5,25$ & 783.15 & 132.8 & -3.3 & 5 & 2.3 & $30-60$ & 40.835 & 0.059 & 96.9 & Claystone \\
\hline$-5,35$ & 792.95 & 178.9 & -6.5 & 7 & 1.6 & $200-500$ & 17.786 & 0.267 & 88.1 & Sandstone \\
\hline 68R-5, 62 & 783.52 & 101.1 & $\begin{array}{r}-0.5 \\
-13.4\end{array}$ & 7 & $\begin{array}{l}1.0 \\
2.4\end{array}$ & $20-60$ & $\begin{array}{l}17.160 \\
30.167\end{array}$ & 0.060 & $\begin{array}{l}60.1 \\
78.5\end{array}$ & Claystone \\
\hline $69 \mathrm{R}-1,20$ & 786.8 & 79 & -17.6 & 5 & 4 & $30-60$ & 29.338 & 0.041 & 71.5 & Claystone \\
\hline $69 \mathrm{R}-2,6$ & 788.16 & 115.2 & -20.6 & 9 & 1.8 & $150-500$ & 31.886 & 0.151 & & \\
\hline
\end{tabular}

Notes: $\mathrm{N}=$ number of samples used for least-squares linear fit; MAD = maximum angular deviation (error akin to angular standard deviation; see Kirshvink, 1980); Susc. = susceptibility. $\mathrm{NS}=$ not studied. Coarse volc. $=$ coarse volcaniclastic sediments. 